\title{
Horticulture and Orchards as New Markets for Manure Valorisation with Less Environmental Impacts
}

\author{
David Fangueiro *, Paula Alvarenga (D) and Rita Fragoso \\ Linking Landscape, Environment, Agriculture and Food-LEAF Research Unit, Instituto Superior de Agronomia, \\ Universidade de Lisboa, Tapada da Ajuda, 1349-017 Lisboa, Portugal; palvarenga@isa.ulisboa.pt (P.A.); \\ ritafragoso@isa.ulisboa.pt (R.F.) \\ * Correspondence: dfangueiro@isa.ulisboa.pt; Tel.: +351-213-653-199
}

check for

updates

Citation: Fangueiro, D.; Alvarenga, P.; Fragoso, R. Horticulture and Orchards as New Markets for Manure Valorisation with Less Environmental Impacts. Sustainability 2021, 13, 1436. https://doi.org/10.3390/su13031436

Academic Editor: Giorgio Provolo

Received: 7 December 2020

Accepted: 25 January 2021

Published: 29 January 2021

Publisher's Note: MDPI stays neutral with regard to jurisdictional claims in published maps and institutional affiliations.

Copyright: (c) 2021 by the authors. Licensee MDPI, Basel, Switzerland. This article is an open access article distributed under the terms and conditions of the Creative Commons Attribution (CC BY) license (https:// creativecommons.org/licenses/by/ $4.0 /)$.

\begin{abstract}
Animal manure management is a real challenge to minimize environmental impacts and ensure that this valuable material is efficiently used in a circular economy context. One of the main limitations for larger use of animal manure as fertilizer is the availability of land to receive it in an area close to the farm. Indeed, animal manure is traditionally used for cereals and animal feed growth, but the soil area occupied with these crops might not be enough to receive all the manure produced and/or part of this soil might have nutrient contents, namely phosphorous, that do not permit further application of manure. Hence, extra land used for other agricultural activities might be an option. The main objective of the present review was to analyse the constraints and solutions to increase the use of manure in horticulture and orchards. Emphasis was given to the legal framework for manure utilization in the EU that might stimulate or restrain such a solution. The main characteristics of manure that might limit or stimulate manure reuse were also described, and the potential of some treatments to valorise manure was analysed. Several examples of alternative uses of manure in horticulture and orchards were examined, and the society and farmers' acceptance of the proposed solution was addressed.
\end{abstract}

Keywords: organic fertilizer; pathogens; ammonia; greenhouse gases; water contamination; farmers' acceptance

\section{Introduction}

The increase in the world population of $\sim 33 \%$ to 2050 should be followed by a $70 \%$ increase in food demand worldwide [1,2]. When considering more specifically meat and dairy products, the increasing demand is also due to the improvement of living conditions in developing countries that will lead to a livestock revolution [3]. In the European Union (EU), a 14\% increase in meat consumption per capita is expected between 2017 and 2030 and, simultaneously, milk production is expected to increase $1 \%$ per year in the same time interval [4]. To attend to such a demand, the livestock production systems have moved from an extensive to a more intensive activity over the last decades, and the livestock density tended to be very unbalanced between EU regions, ranging from 0.2 livestock units/ha of agriculture area (in Bulgaria) to 3.8 (in The Netherlands) [5]. Furthermore, four countries/regions (Denmark, The Netherlands, Northern Germany, and Western France) host a third of all EU farm animals (especially dairy, pigs, and poultry) [6].

Simultaneously, the size of livestock farms also increased, moving to industrialized farms, concentrated in the same area and, generally, with low soil availability. This is especially the case for pig [7] and poultry [8] productions, while the dairy and beef sector, despite a trend to intensification in some regions, continues to be more extensive $[9,10]$.

One of the main consequences of this intensification is the production of large volumes of manure. Indeed, the total amount of animal manure produced each year in Europe is estimated to be close to 1400 million $t$ (32\% cattle slurry, 11\% pig slurry and 8\% poultry litter) [11]. This amount of manure represents 80-140 million $t$ of nitrogen (N) and 
20-30 million $\mathrm{t}$ of phosphorus $(\mathrm{P})$ per year, which is equivalent to 1-2 times the amounts of $\mathrm{N}$ and $\mathrm{P}$ applied annually through mineral fertilizers $[12,13]$.

This large volume of manure is also responsible for a major part of ammonia $\left(\mathrm{NH}_{3}\right)$ emissions (1.4 million $\mathrm{t} \mathrm{N-N_{3 }}$ /year in the EU) [14], and for the emission of 73 million t $\mathrm{CO}_{2}$ eq/year of greenhouse gases, which represents $50 \%$ of the nitrous oxide $\left(\mathrm{N}_{2} \mathrm{O}\right)$ emissions and $15-25 \%$ of the methane $\left(\mathrm{CH}_{4}\right)$ emissions from agriculture in the $\mathrm{EU}[15,16]$. Furthermore, manure management in the EU also led to the loading of 4 million $\mathrm{t} N$ /year in water bodies [17].

An obvious solution to minimize such environmental impacts, during and after soil application, is to increase the application area and, simultaneously, to decrease the application rate. However, the soil area available to receive animal manure at farm scale might be limited and some productions, as swine and poultry, generally have no soil associated to the farm and have, therefore, to export all the manure. Hence, extra agricultural land, not yet receiving manure, are needed.

Direct application of raw manure in an area close to the farm is the common practice in most EU regions, and it remains the best option (cheaper, lower energy use). Nevertheless, another option to minimize the environmental impacts of animal manure is its treatment, such as solid-liquid separation [18] or acidification [19]. The solid fraction obtained by separation of manure could be more efficiently transported over longer distances, while the liquid fraction might be used directly at the farm, for irrigation.

Till now, in Europe, animal manures and slurries are mainly applied in grassland and arable crops, like cereals [20]. Nevertheless, these materials could be applied in many other crops, and as dressing fertilization, if some constraints to their application are eliminated. Therefore, the solution analysed here is the wider agricultural use of animal manures, like in horticulture and orchards, and with the option of basal and dressing fertilization, in a way to increase their valorisation and nutrients recycling.

The reuse of animal manure in such agricultural activities is also a key solution to minimize the environmental impact of mineral fertilizers production, and to minimize the dependency of EU regarding P fertilizers import. Indeed, the increase in mineral fertilizers prices has led to a growing interest from farmers in the use of organic materials, like manures, as nutrients sources. Moreover, the significant decline of soil organic matter (SOM) in many Mediterranean regions obliges farmers to look at organic fertilizers as attractive products [21], in opposition to the almost exclusive use of mineral fertilizers in the last decades.

The present review aims to analyse the constraints and solutions to increase the use of manure in horticulture and orchards, with special emphasis on the legal framework for its utilization in the EU, the main characteristics of manure that might limit or stimulate its reuse, and the potential of some treatments to its valorisation. An exhaustive presentation of alternative uses of manure in horticulture and orchards is also compiled and, finally, a key parameter for the success of this solution, society and farmers' acceptance, is addressed.

\section{Legal Framework to Use Manure in the EU}

The legal framework and farmers/society acceptance are the two main drivers to successfully introduce new practices. The main EU regulations dealing with animal manure management were clearly detailed by Sommer et al. [22]. Nevertheless, the interest in organic materials has been growing exponentially and several updates of regulation occurred over the last years. Hence, in this review, the EU legislation will be briefly presented and analysed to understand to which extent it can contribute to stimulate or restrain the use of animal manure as fertilizer for alternative crops and plants.

According to the European Commission [23], animal manures are considered as animal by-products from category 2 and can be directly applied to soil without previous treatment. The transport of manure between EU countries also follows some strict rules, and the receiving country can refuse or impose some specific conditions, for instance, the sterilization of the material. 
The Good Agricultural and Environmental Conditions proposed by the EU Council [24] incentives the use of organic materials, namely manures, since it promotes the maintenance of SOM as a way to reach food security and climate change mitigation [25]. However, in most countries, this recommendation has not been included, even though such measure could also contribute to the " 4 per Thousand" initiative as a climate change mitigation measure [26,27].

The Directive 2010/75/EU on industrial emissions (the Industrial Emissions Directive or IED) [28] aimed at reducing gaseous emissions by adopting the Best Available Techniques (BAT). Nevertheless, it includes only the intensive pig and poultry farms and, since most of these farms have no associated soil area, it does not consider manure spreading. An increase of agricultural land available to receive slurry would be globally beneficial, not only because it could reduce ammonia emissions by the adoption of BAT for manure application, but also because it would allow a decrease in the application rates. Furthermore, a reduction of application rates would also be beneficial in terms of GHG emissions.

The Groundwater Directive [29], developed in response to the requirements of Article 17 of the Water Framework Directive [30], defines quality criteria regarding nitrates and pesticide concentrations in groundwater, as well as threshold values for other pollutants, namely cadmium (Cd). Regarding the nitrate issue, replacement of $\mathrm{N}$ mineral fertilizers by manure should not be a problem, since recent studies indicated that the risk of nitrate leaching can be lower in manure amended soils than in soils receiving mineral fertilizer [31]. Attending that $P$ fertilizers are a significant source of $\mathrm{Cd}$ [32,33], replacement of the source of $\mathrm{P}$ for plants, from mineral fertilizers to manure, is in line with the Groundwater Directive objectives.

The EU Nitrates Directive [34] is the most impacting measure when dealing with manure application, since it limits the application of $\mathrm{N}$ fertilizers to protect waters from nitrate contamination and should therefore be seen as one of the main constraints to the increase of manure receiving agricultural areas, namely to nitrate vulnerable zones. This directive defines the nitrate vulnerable zones (NVZ), where a maximum of $170 \mathrm{~kg} \mathrm{~N} \mathrm{ha}^{-1}$ can be applied to soils through animal manures. In countries where the NVZ area could increase, there will be an urgent need to increase the manure receiving surface area and, consequently, it can be said that this directive supports the solution proposed here. Nevertheless, some new areas available to receive manure might also be classified as NVZ. The recent project SAFEMANURE might be seen as a strong opportunity and support to the concept analysed here [35]. Indeed, its main objective is to revise the nitrate directive, allowing the use of $\mathrm{N}$-rich sub-products from animal manure, with the same conditions as those imposed on mineral $\mathrm{N}$ fertilizers [35], which are based on soil nutrients status and crop requirements. Even if it implies performing some "heavy" treatment to manure, it will surely open larger markets for animal manure.

The EU climate and energy targets [36] might have an indirect impact on the replacement of mineral fertilizers by animal manure in some regions. Indeed, one of these targets is a $40 \%$ decrease in GHG emissions, relative to 1990, and one of the main contributors for GHG emissions is the mineral fertilizers industry [37]. Decreased application of $N$ obtained through the high-energy intensive Haber-Bosch process will drastically reduce the carbon footprint of the agriculture sector. Hence, the replacement of mineral fertilizers by manure should contribute to these targets. Nevertheless, animal production, the main contributor to $\mathrm{CH}_{4}$ emissions [38], might also need to decrease its emissions to attend to these GHG targets, with a direct impact on the amount of manure available.

The revised National Emission Ceilings Directive (NECD) [39] imposes a strict reduction of gaseous emissions, namely $\mathrm{N}_{2} \mathrm{O}, \mathrm{CH}_{4}, \mathrm{NH}_{3}$, volatile organic compounds and sulphur dioxide that are strongly related to manure management. This might appear as a major constraint to the implementation of the solution proposed here, since a wider handling and soil application of manure might enhance such emissions. However, some manure pretreatments and balanced soil applications might help to minimize these gaseous emissions. 
Other legislation, or recommendations, as the Circular Economy Package [40], New Waste Framework Directive [41], New Landfill Directive [42], and New Fertilizing Products Regulation [43], might also influence the acceptance of the solution proposed here. Indeed, despite the fact of not having a direct impact on manure management and utilization, it will contribute to disseminate/support the use of manure as fertilizer and as an ecofriendly solution.

The CAP 2014-2020 included topics such as climate change mitigation, resource efficiency and soil, water, and land management [44]. More specifically, Rural Development Programmes (RDPs) set up by member states, or regions, on behalf of CAP 2014-2020, must attend almost four of the six EU Rural Development Policy priorities of which Priority 4 (P4) "Restoring, Preserving and Enhancing Ecosystems" and Priority 5 (P5) "Dealing with resource-efficient, climate-resilient economy", can directly influence the use of manure for new cultures. Actually, among other objectives, P4 aimed at "Preventing soil erosion and improving soil management", while another one from P5 deals with "carbon conservation and sequestration in agriculture". Hence, wider use of manure for fertilization and soil enhancement is in line with CAP recommendations. Nevertheless, P5 also includes a focus area on "reduction of greenhouse gases and ammonia emissions from agriculture" that might limit the reuse of manure if no mitigation measures are adopted to minimize $\mathrm{NH}_{3}$ emissions. Hence, it is important to ensure that mitigation measures to minimize gaseous emissions are adopted in these new application areas. The "greening payments", as part of the CAP direct payments, might also be an important tool to support a larger use of animal manure as an alternative to mineral fertilizers and soil enhancers.

The Post 2020 CAP is being designed attending Good Agricultural and Environmental Conditions that includes several measures to minimize $C$ losses from soil and increase of SOM, as well as the improvement of nutrients management at farm level [45]. It is to believe that the solution proposed in this review is in line with the new CAP policies. Organic farming could be an excellent market to reuse the surplus of manure available in some regions. However, the use of organic fertilizers in these farms is strictly ruled by EU Regulation 2018/848 [46], and only allows the use of manure produced in organic farms, is strictly prohibited the use of manure from intensive animal farms with no associated soil.

Table 1 summarizes the most important EU regulations and policies dealing with animal manure management that may potentiate or restrain the use of manure as a fertilizer for new crops and plants.

Table 1. Main EU regulations and policies dealing with animal manure management and their incentives and constraints to the use of manures as fertilizers for new crops and plants.

\begin{tabular}{|c|c|c|}
\hline & Incentive & Constraint \\
\hline CAP 2014-2020 and Post 2020 CAP $[44,45]$ & $\begin{array}{l}\text { Improvement of soil management and soil } \\
\text { erosion prevention (Priority 4) } \\
\text { Fostering carbon conservation and } \\
\text { sequestration in agriculture } \\
\text { and forestry (Priority 5) }\end{array}$ & $\begin{array}{l}\text { Reduction of greenhouse gas and ammonia } \\
\text { emissions from agriculture might limit the use } \\
\text { of manure or imply the adoption of mitigation } \\
\text { techniques (Priority 5) }\end{array}$ \\
\hline Groundwater Directive [29] & $\begin{array}{l}\text { Decrease of Cd contamination induced by } \mathrm{P} \\
\text { fertilizers application }\end{array}$ & $\begin{array}{l}\text { Potential risk of nitrate leaching similar or } \\
\text { lower than with mineral fertilizer }\end{array}$ \\
\hline Nitrates Directive [34] & $\begin{array}{l}\text { SAFEMANURE project for nitrate directive } \\
\text { (ND) revision: equivalence of N rich } \\
\text { sub-products from animal manure relative to } \\
\text { mineral fertilizers in terms of ND rules }\end{array}$ & $\begin{array}{l}\text { Limited } \mathrm{N} \text { application in } \\
\text { nitrate vulnerable zones }\end{array}$ \\
\hline Climate and Energy targets [36] & $\begin{array}{l}\text { Decrease of mineral fertilizers production to } \\
\text { decrease GHG emissions and replacement by } \\
\text { animal manure }\end{array}$ & $\begin{array}{l}\text { Manure management also leads to GHG } \\
\text { emissions and animal production is the main } \\
\text { contributor to } \mathrm{CH}_{4} \text { emissions: potential } \\
\text { decrease of the amount of manure produced }\end{array}$ \\
\hline $\begin{array}{l}\text { Revised National Emission Ceilings } \\
\text { Directive (NECD) [39] }\end{array}$ & / & $\begin{array}{l}\text { Manure is a strong contributor to most of the } \\
\text { gases ruled by the NECD. Manure treatment } \\
\text { will be needed. }\end{array}$ \\
\hline
\end{tabular}




\section{Main Characteristics of Dairy, Pig, and Poultry Manures}

Animal manure is a material rich in macro and micronutrients that is suitable to fully, or partially, replace mineral fertilizers. The first limitation of manure, when compared to mineral fertilizers, is the fact that it contains a mixture of several elements and does not allow the application of a single element, e.g., $\mathrm{N}$ or P. The second main limitation is the low concentration of nutrients, namely in slurries (liquid manure) and liquid fraction obtained by slurry solid-liquid separation (Figure 1). Indeed, nutrient-exportation in slurry, from livestock farms to arable or horticultural farms, implies larger costs to transport the same amount of nutrients, when comparing to mineral fertilizers.

Last but not least, animal manure is a heterogeneous material with dry matter (DM) content ranging from 10 to $140 \mathrm{~g} \mathrm{~kg}^{-1}$ in liquid manure (slurry), and from 210 to $460 \mathrm{~g} \mathrm{~kg}^{-1}$ in solid manure ( $\sim 900 \mathrm{~g} \mathrm{~kg}^{-1}$ in poultry manure) [47]. The DM content has a direct influence on the nutrient content in slurries, namely the concentration of available $\mathrm{N}, \mathrm{P}$ and potassium (K) (Figure 2). The variable composition of manure from different animal production systems and farms is also a serious drawback. In fact, it is highly relevant for farmers, who intend to replace mineral fertilizers with manure, to have a homogenous material between applications, so that they know exactly the amount of nutrients they are applying, and know, for sure, their availability to the plant. Considering $\mathrm{N}$, the mean concentrations in slurries range from 4 to $10 \mathrm{~g} \mathrm{~kg}^{-1}$, and in solid manure from 7.7 to $34.1 \mathrm{~g} \mathrm{~kg}^{-1}$, depending on the animal species (Figure 1) [48]. Furthermore, there is also a huge variability between farms, as illustrated by the error bars of Figure 1 with data from more than 1000 samples of manure collected in different farms for each type of manure (except for chicken slurry, where $\mathrm{N}=602$ ).

One of the main advantages of using mineral fertilizers is the fact that the whole amount of nutrients is readily available for plants. On the contrary, in animal manure only a fraction of the nutrients content is readily available, while the remaining part can be released later, depending on several factors, such as soil conditions. Nitrogen availability in animal slurry varies between 40 and $60 \%$ of the total $\mathrm{N}$, while $\mathrm{P}$ and $\mathrm{K}$ availability are more homogeneous between animal species, and close to 40 and $90 \%$, respectively [47]. The mineralization and nitrification processes in a soil amended with slurry depend on slurry characteristics, as the $\mathrm{C}: \mathrm{N}$ ratio or the $\mathrm{pH}$, but the main drivers are the soil characteristics [49].

As occurred with the composition of manure relative to mineral fertilizers (multi elements versus single or selected elements: $\mathrm{N}, \mathrm{P}, \mathrm{K}$, or others), the ratio between nutrients in manure, namely the N:P ratio, are fixed (against tailor-made ratios in mineral fertilizers) and not always adapted to the crops' requirements. Manure application is usually based on $\mathrm{N}$ demand and consequently leads to excessive supply of $\mathrm{P}$ [50]. The solution is to base the manure application on $P$ requirements, which will provide an insufficient amount of $\mathrm{N}$ to the plant, requiring $\mathrm{N}$ supplementation via mineral fertilization. Another option is to use an adequate treatment (see the next section) to modify the manure N:P ratio to the desired value, considering the crops' needs.

As already referred, manure management is responsible for close to $60 \%$ of ammonia emissions in Europe [51], and an increase of manure handling and application to a larger area might enhance such emissions. Nevertheless, several solutions were proposed to minimize ammonia emissions associated with manure management (some of them will be detailed in the next section). Furthermore, mineral fertilizers, as urea or ammonium sulphate, also lead to ammonia emissions, and their replacement by manure should not induce an exponential increase in $\mathrm{NH}_{3}$ emissions. 

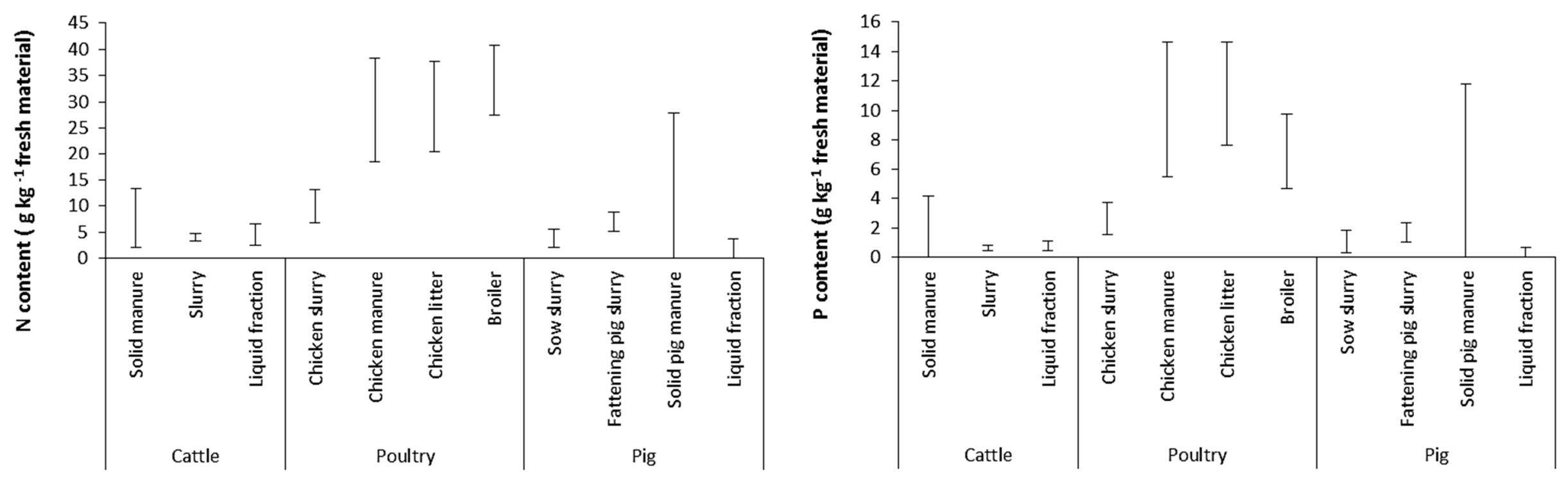

Figure 1. Range of $\mathrm{N}$ and $\mathrm{P}$ contents in raw and treated manure from cattle, poultry and pig production (adapted from [48]). 

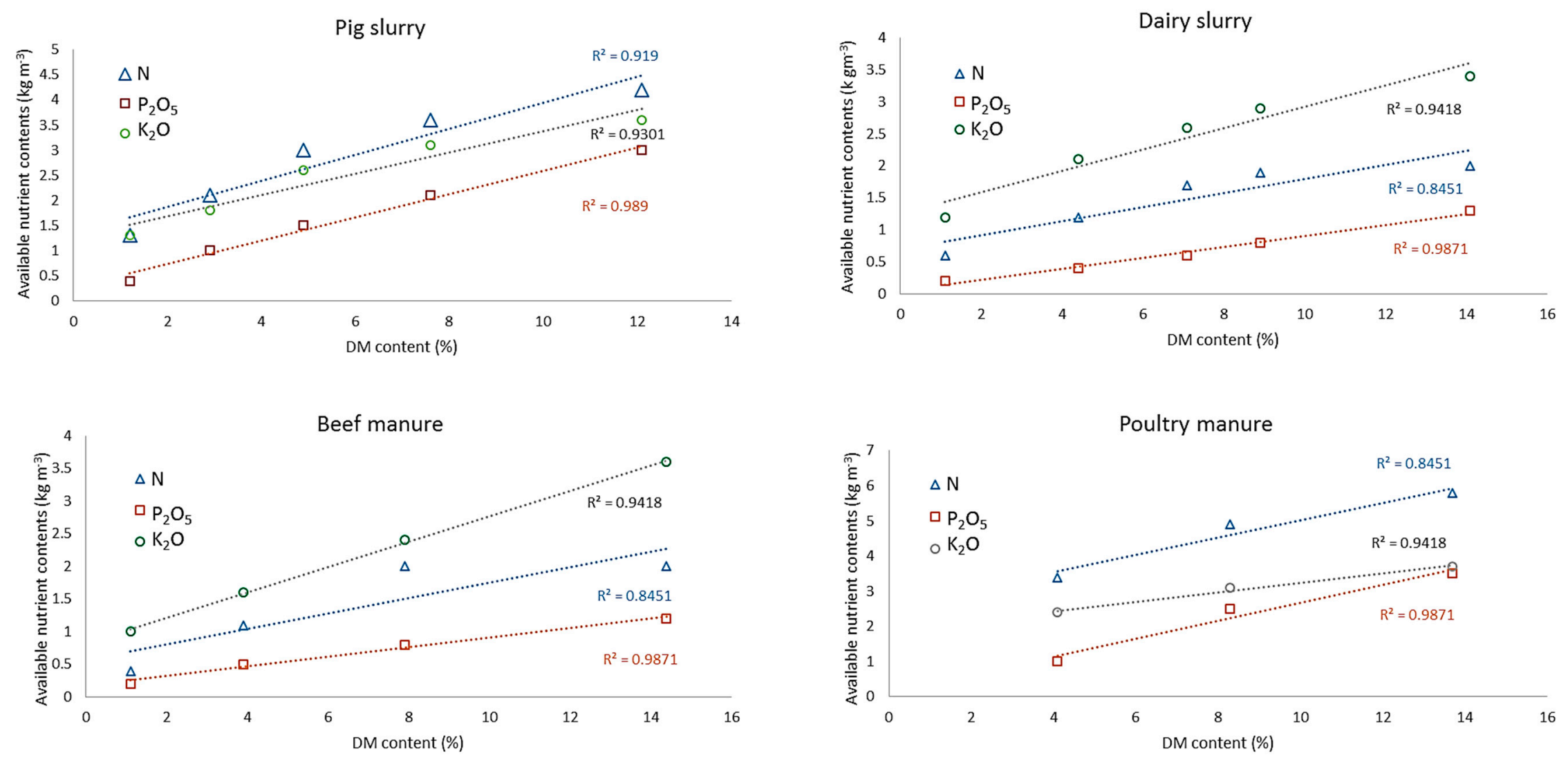

Figure 2. Relationship between the dry matter content and the $\mathrm{N}, \mathrm{P}_{2} \mathrm{O}_{5}$ and $\mathrm{K}_{2} \mathrm{O}$ available content in manures (pig, dairy, beef and poultry manure) (adapted from [47]). 
One of the issues when dealing with animal manure is related to the odours produced along the whole management chain, especially during the soil application stage $[52,53]$. As it can be seen in Figure 3, these odours are due to the presence of a larger number of organic compounds with a predominance of acetic and propionic acids, as well as 4methylphenol [53]. The increasing number of complaints in rural areas due to manure application to soil are mainly related to odours issues. The use of manures in new cultures, and new areas, might lead to more complaints and even produce a negative image of the products fertilized with manure. It is therefore essential to adopt some mitigation measures to minimize odour emission over the whole management chain, like the slurry injection, which proved to be an efficient solution to minimize odour emissions during the application stage (Figure 3).

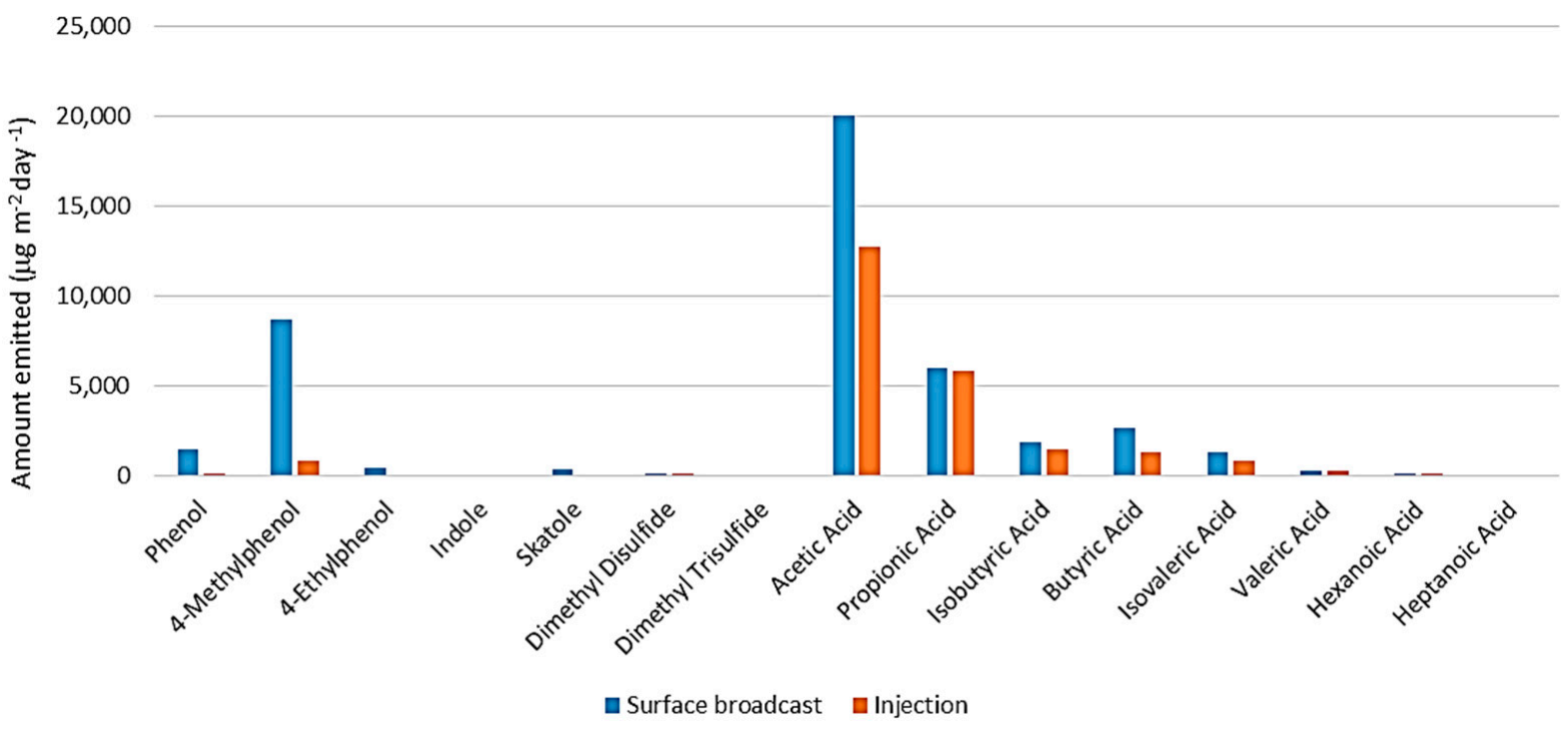

Figure 3. Odorous compounds emission during swine manure application by surface broadcast or injection (adapted from [53]).

Weed seeds are a major concern for agriculture, namely for horticulture, or again for organic farming since no chemical products can be used to fight invasive species [54]. Animal manure might contain a significant amount of weed seeds [55], depending on the animal species and on the stabilization technology adopted (composted or not) (Figure 4). Nevertheless, the impact of manure application to soil on weed growth is not clear, with studies indicating a low impact or no impact at all $[55,56]$ and others reporting a significant impact [57]. This is mainly related to seeds' viability in manure, highly dependent on temperature, with Eghball and Lesoing [58] reporting that at a temperature close to $60^{\circ} \mathrm{C}$, reached during a certain composting time interval, most of the weed seeds were inactivated. Westerman and Gerowitt [59] also indicated that some seeds might also be inactivated during manure storage due to the toxic conditions of the mixture. Composting appears as the best solution to obtain a "weed free" material, even if long-term storage might be sufficient to minimize the risk of weed proliferation [55].

Animal manure contains valuable elements and organic matter that contributes to soil productivity enhancement, but also contains pathogenic microorganisms that can reach humans if appropriate manure management is not secured [60]. Among the pathogenic microorganisms that can potentially be found in animal manure, one can find (1) bacteria, such as Salmonella spp., Campylobacter spp., Escherichia coli or Listeria monocytogenes; (2) viruses, such as Polioviruses, Rotavirus, Avian influenza virus or Hepatitis A and E; (3) parasites, such as Cryptosporidium paroum, Giardia lamblia; and (4) fungi [60]. Therefore, animal manure application to agricultural soil represents a potential risk to human health, 
both for workers and for consumers, and this issue needs to be addressed properly to broaden the agricultural crops with potential for manure application. Nevertheless, the probability of such contamination is relatively low, since these pathogens are sensitive to several manure properties, like redox potential, temperature, and $\mathrm{pH}$ [61], which can be manipulated to adequately hygienize the manures before their use. Indeed, Semenov et al. [62], reported that E. coli in manure is much more resistant in anaerobic conditions than in aerobic conditions. For this reason, storage of manure in aerobic conditions is usually pointed out as the most advantageous method of manure hygienization, namely in the case of solid manure $[63,64]$.

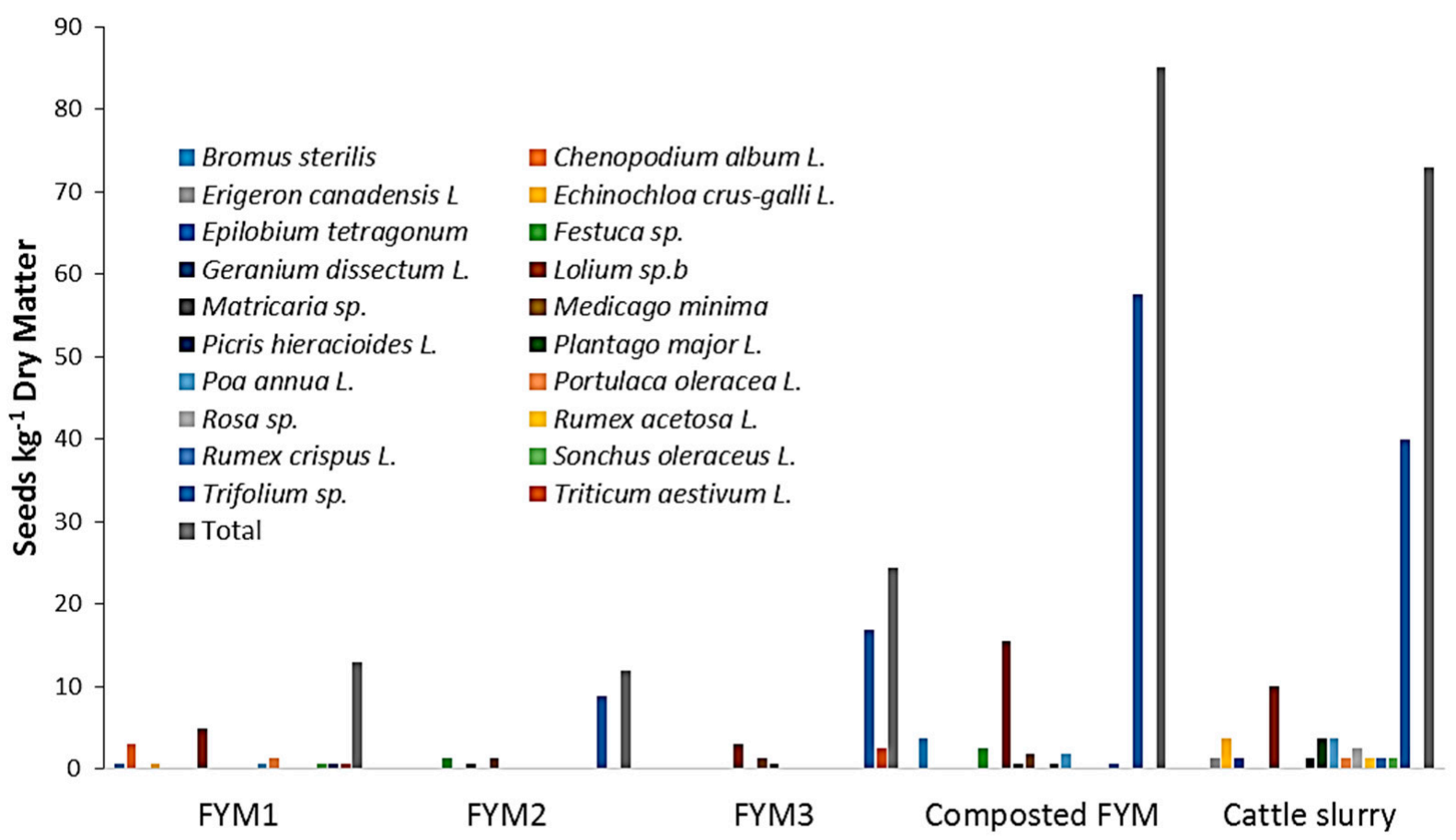

Figure 4. Presence of germinating seeds in animal manure (adapted from [55]).

After manure application to soil, the pathogens will either survive (and replicate) or die, which depends on soil characteristics, weather conditions and other environmental factors [65]. The impact of soil characteristics and conditions on pathogens' survival has been extensively reviewed by Alegbeleye and Sant'ana [60]. The manure-borne pathogens may contaminate agricultural products, which is critical in horticulture, and eventually may be transported along the soil profile and reach the water bodies $[66,67]$.

The dry matter content of manure is also an aspect to be considered when its hygienization is required, since the liquid manure is usually more homogeneous than the solid manure, and consequently more homogeneously contaminated, making it more prone to release and transport pathogenic microorganisms [68,69].

Depending on the plant or crop considered, the pathogens' issue might be relevant, for example for vegetables, usually consumed crude, when manure is applied as dressing fertilization special attention should be given to the time interval between manure application and harvest.

Animal manure is mainly produced in intensive farms with high livestock rates, which implies the need for pharmaceuticals' administration to animals, to prevent diseases and infections, but also to control their hormonal system [70,71]. Recently, a list of antimicrobial agents and other compounds that can be found in animal manure has been published and analysed in a European Commission report [72]. Despite the measures adopted by several countries to ban the use of antibiotics and growth hormones in animal production, it is still a common practice in several world regions [73]. According to Hou et al. [74], 
the risk to find sulphonamides, tetracyclines, quinolones and macrolides antibiotics in swine manure is higher than in poultry manure and cattle manure presented the lowest concentrations. The authors explained such differences with the higher and more frequent doses of antibiotics usually administrated to swine, comparatively to cattle, motivated by the growing conditions offered to pigs, that are more prone to develop infections and diseases, sometimes a consequence of poor animal welfare conditions (e.g., poor housing ventilation, small area).

An extensive review of pharmaceuticals, hormones and selected microorganisms that can be potentially found in animal manure has been performed by Ghirardini et al. [73]. According to these authors, the hormones' concentrations in manure are always significantly lower than antibiotics' concentrations. As an example, the same authors referred that the highest concentrations of hormones were $2.8 \times 10^{4} \mathrm{ng} / \mathrm{L}$ and $2.1 \times 10^{4} \mathrm{ng} / \mathrm{L}$ in raw pig and cattle manure, respectively, against values of antibiotics concentrations that can reach $1.1 \times 10^{8} \mathrm{ng} / \mathrm{L}$ in swine manure and $5.9 \times 10^{6} \mathrm{ng} / \mathrm{L}$ in cattle manure [73].

\section{Treatment Strategies to Increase Manure Acceptance for Farmers and Society}

Several strategies were proposed to facilitate manure management and minimize the concomitant environmental impacts [17,18,75-77]. In order to have a holistic perspective of the manure management/treatment schemes, Figure 5 presents the most common treatment pathways, identifies the co-products obtained and shows the possible integration of the different processes: (i) acidification/additives, (ii) separation, (iii) biological, (iv) membrane and (v) thermal.

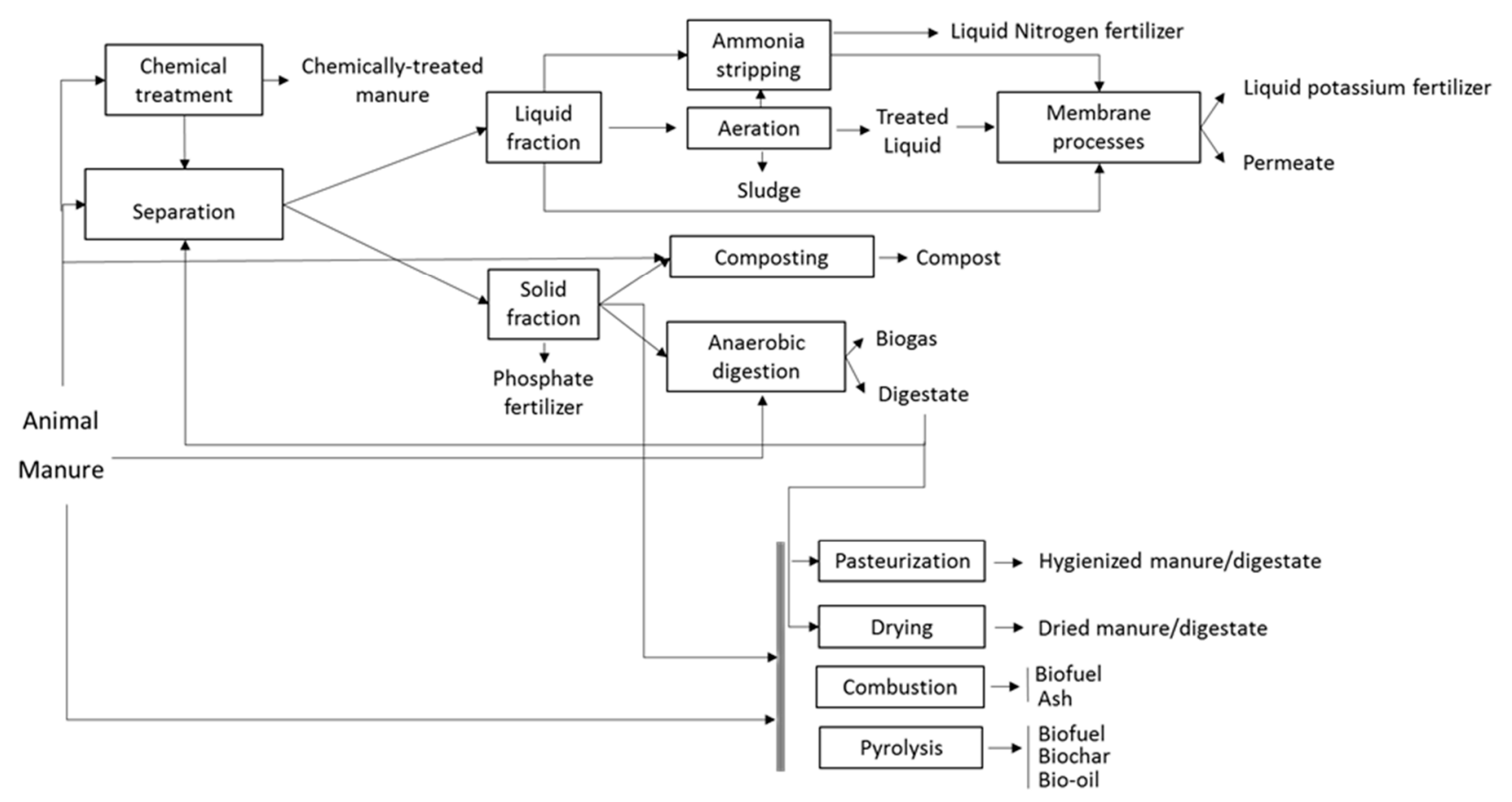

Figure 5. Main strategies for manure management/treatment and resulting co-products.

From Figure 5, it is possible to conclude that manure management/treatment strategies can result in a complex system, sometimes including highly technological solutions. The selection of an appropriate treatment scheme should be based on a fit-for-purpose approach, meaning that depending on the specific case scenario (land availability, odour nuisance, excess of nutrients, risk of water pollution, etc.) the best available strategy can be different. A whole-farm perspective, considering the interactions between processes, nutrient flows and potential drawbacks, is always the best strategy. 
As mentioned in the previous section, manure management largely contributes to ammonia emissions in Europe and, therefore, mitigation strategies need to be implemented. The most common practice is chemical treatment, using acids or other additives. Manure acidification was broadly reviewed by Fangueiro et al. [19], who highlighted that beyond minimizing ammonia emissions, it has other positive impacts, such as the improved efficiency of the solid-liquid separation, the increase of nutrients availability in soils, and the disinfection effect. According to Lin et al. [78], acidification is also a highly effective manure management option to reduce antibiotic resistance, as it promotes the degradation of sulphonamide antibiotics and decreases the accumulation of antibiotic resistance genes. This fact is beneficial for its potential use in horticulture, but attention should be given to possible corrosion effects and toxicity to plants due to the presence of strong acids.

Furthermore, acidification can render treatment by biological processes more difficult due to the inhibition of microbial activity and, therefore, its adoption should consider the subsequent treatment processes that will be applied.

Commercially available additives can be used for other purposes than ammonia emission mitigation, such as odour control, prevention of crust formation, foam reduction and nutrient preservation. Duerschner et al. [79] studied the effects of additives (Coban ${ }^{\circledR}$ 90, Manure Magic ${ }^{\circledR}$, MOC-7, More Than Manure ${ }^{\circledR}$, Sludge Away, and Sulfi-Doxx) and disinfectants $\left(\right.$ Clorox $^{\circledR}$, Pi Quat, Tek-Trol, and Virkon ${ }^{\mathrm{TM}}$ ) on swine slurry characteristics and verified that the use of additives led to a significant increase in DM, TN, $\mathrm{P}_{2} \mathrm{O}_{5}, \mathrm{Ca}$, $\mathrm{Mg}, \mathrm{Zn}, \mathrm{Fe}, \mathrm{Mn}$, and $\mathrm{Cu}$. The authors also found that the disinfectants had an influence on the antibiotic concentrations of swine slurry, e.g., concentrations of chlortetracycline and tiamulin were significantly lower for the treatments containing Tek-Trol [79]. Despite the potential positive effects of additives, their cost and lack of knowledge regarding their cumulative effect on soil and health risks for humans, even more relevant for crops eaten crude, prevent wider adoption of this practice.

Solid-liquid separation of manure is commonly implemented on-farm to obtain fractions that are easier to handle, minimise clogging problems and avoid treating or transporting high amounts of water. Furthermore, it improves homogeneity and facilitates the following processing steps.

The separation process can be achieved using different types of equipment, e.g., rotary screens, static screens, decanter centrifuge, screw press, filter pressing and dissolved air flotation (DAF) $[18,80]$. The characteristics of the two fractions obtained highly depend on the equipment used, but in all cases, the liquid fraction has a low content of solids and organic matter and contains available $\mathrm{N}$ and $\mathrm{K}$; whereas the solid fraction is rich in organic matter and retains organic $\mathrm{N}$ and $\mathrm{P}$ (organic and mineral) [18,75].

Regarding antibiotic residues, their solubility and sorption properties will dictate their partitioning between the liquid and solid fractions [81], and the separation technique efficiency will also affect that partition, as it influences the total solids content of the resulting fractions.

Biological processes, under aerobic or anaerobic conditions, are widely used to remove the excess nutrients and organic load. Aerobic processes include composting and aeration. Manure composting has been identified as a suitable treatment option [75-77,82,83], which can be applied directly to solid manure or to the solid fraction obtained by separation processes. If well performed, the resulting compost has stabilized organic matter, reduced odour and is free of pathogens and weeds [75,84]. Bernal et al. [84] emphasised that composting can be economically viable, if it produces high-quality compost, and reviewed the factors that affect manure-based composts' quality. 
Inactivation of pathogens (e.g., E. coli) during composting has been reported on studies using different types of manure, e.g., bovine and chicken $[85,86]$. The high temperature achieved during the process is the most effective factor for the inactivation of pathogens within a reasonable timeframe $[87,88]$. Nevertheless, according to Thomas et al. [89], several mechanisms influence E. coli reduction. The same authors found that the $\mathrm{C} / \mathrm{N}$ ratio and moisture content of chicken manure significantly affected the reduction of $E$. coli. during composting, with the ratio of 10:1 showing the faster reduction.

Another aspect worth mentioning is the effect of composting on micro-pollutants present in manure, namely veterinary drugs as antibiotics, hormones, and heavy metals. The use of antibiotics in livestock farming promotes the growth of antibiotic-resistant bacteria in the animals' gastrointestinal tract, leading to their presence in manure $[88,90]$. Studies have shown that manure composting reduces the concentration of antibiotics and antibiotic-resistant pathogens [91,92].

As mentioned previously, the presence of natural and synthetic hormones in manure is of major concern. Therefore, it is important to study how treatment technologies influence the presence of these compounds. A recent study by Havens et al. [93] observed lower content of progesterone in the runoff from fields where composted manure was applied, which can be the result of its degradation during composting.

Manure can have a significant content of heavy metals (e.g., $\mathrm{Cu}$ and $\mathrm{Zn}$ in pig manure) and the common practice of solid-liquid separation leads to their concentration in the solid fraction. Nevertheless, there is evidence that composting can minimize heavy metals mobility [94]. Moreover, the integration of additives in the composting process can enhance heavy metals stabilization. Chen et al. [95] observed that integrating bamboo charcoal and bamboo vinegar into pig manure composting piles controlled the mobility of $\mathrm{Cu}$ and Zn. Kumar et al. [96] verified that adding wood or wheat-straw biochar and inoculum promoted suitable conditions for the complexation of metal ions reducing their mobility.

A new trend in composting process is integrating black soldier fly larvae (BSFL) as an inoculum, converting manure into larval biomass and compost. The larval biomass can be used in animal feedstock or for bioenergy production [96-98]. According to Liu et al. [98], this practice improved the quality and maturity degree of compost, increased nutrients content and contributed to antimicrobial activity against pathogens.

Aeration is another aerobic biological treatment route, but it is not considered a good option because it promotes nitrification-denitrification, leading to nitrogen gas emission and loss of fertilizer value. Therefore, it is rarely used and can be followed when there is the need to reduce the nitrogen content of slurry or manure liquid fractions, eventually to obtain a lower N:P ratio. Many studies have proven the efficiency of aeration for $\mathrm{N}$ removal and more recently have focused on the effect of operational parameters on $\mathrm{N}_{2} \mathrm{O}$ emission mitigation (adopting intermittent aeration or acting on aeration flow rates) [99].

Anaerobic digestion (AD) is also a biological treatment process that has the advantage of recovering energy from manure as biogas $[100,101]$. It can be directly applied to manure or to the solid fraction. The last option enhances biogas production yield, as the substrate fed to the reactor has higher volatile solids' content. Adoption of co-digestion also promotes better bioconversion by synergetic effects between the manure and the other co-substrates, e.g., agricultural or agro-industrial wastes [102-104].

Regarding pathogens inactivation, AD effectiveness is dependent on the operational conditions. A thermophilic regime is necessary to guarantee the inactivation of bacteria, viruses with moderate resistance, and infectious stages of parasites [87]. Hence, when the objective is to use the digestate as dressing fertilization, particularly in horticulture, this operational regime is recommended. Nevertheless, the mesophilic AD also promotes the decrease of pathogens, but a complementary treatment is necessary to achieve hygienization, for example, pasteurization or additives addition [87]. 
Regarding heavy metals, it should be mentioned that they can have two antagonistic effects on the AD process, either enhancing methane production or causing microbial inhibition [105]. On the other hand, heavy metals speciation is modified during AD (soluble metals are transformed into carbonate, phosphate or sulphide precipitates), influencing their bioavailability, with the operational parameters significantly affecting their speciation [106].

Anaerobic digestion has been reported to remove antibiotic residues, antibioticresistant bacteria, and antibiotic resistance genes, with higher degradation rates for the thermophilic regime [60,81]. However, Gurmessa et al. [107], that reviewed several studies on the removal of veterinary antibiotics and antibiotic resistance genes during the $\mathrm{AD}$ process, concluded that AD does not guarantee the complete removal of these compounds. To achieve the required efficiency, the authors recommend a thermal pre-treatment (70 to $180{ }^{\circ} \mathrm{C}$ ) or a post-AD treatment (separation, composting of the solid fraction and phytodepuration of the liquid fraction).

Besides biogas used as an energy source, the AD process produces digestate. The digestate can be processed without previous solid/liquid separation, for example by composting, producing a stable material to be used as fertilizer.

If the solid/liquid separation is implemented, the liquid fraction of the digestate can be handled to obtain liquid fertilizers, an N and K liquid fertilizer, as shown in Figure 5 [108-111]. In fact, in areas where there is an $\mathrm{N}$ surplus it is a good strategy to implement $\mathrm{N}$ recovery processes (e.g., struvite formation, membrane filtration or $\mathrm{NH}_{3}$ stripping), producing a mineral fertilizer that is easier to transport and to apply [112-114]. Even if there is no $\mathrm{N}$ surplus, processing manure or digestate into an $\mathrm{N}$ fertilizer can eliminate, or at least minimize, some of the constraints associated with the direct use of manure.

As seen in Figure 5, thermal processing of manure includes drying, combustion, and pyrolysis. Drying largely reduces the manure volume (facilitating its transport) and produces a stable and hygienized product. However, to minimize the associated costs, it should be applied to manures with high dry matter (above $30 \%$, e.g., poultry manure) [77]. When the adopted treatment strategy includes the $\mathrm{AD}$ process, the heat resulting from combined heat and power (CHP) conversion of the biogas can be used to dry the digestate.

One of the objectives of the present review on manure treatment strategies was to access to what extent they would contribute to eliminate or minimize manure characteristics that are considered limitations for its acceptance by farmers and society. In this sense, the authors present a scoring matrix (Table 2) summarizing the effects of the treatment, in their expert opinion and according to the literature reviewed, on the parameters considered as key limitations to broaden manure use. 


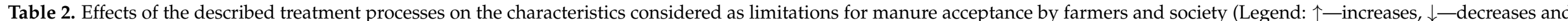
$\rightarrow$ no effect).

\begin{tabular}{|c|c|c|c|c|c|c|c|c|c|c|}
\hline Treatment Process & Product & Dry Matter & Organic Matter & Available/Total N & Available/Total P & N:P:K & Active seeds & Pathogens & Micro-Pollutants & Heavy Metals \\
\hline Acidification & Acidified manure & $\uparrow$ & $\rightarrow$ & $\uparrow$ & $\uparrow$ & $\uparrow$ & $\downarrow$ & $\downarrow$ & $\downarrow$ & $\uparrow$ \\
\hline Separation process & Solid fraction & $\uparrow$ & $\uparrow$ & $\downarrow$ & $\uparrow$ & $\downarrow$ & $\downarrow$ & $\uparrow$ & Depends on their solubility and sorption & $\uparrow$ \\
\hline & Liquid fraction & $\downarrow$ & $\downarrow$ & $\uparrow$ & $\downarrow$ & $\uparrow$ & $\downarrow$ & $\downarrow$ & properties; and on separation efficiency & $\downarrow$ \\
\hline Composting & Compost & $\uparrow$ & $\uparrow$ & $\downarrow$ & $\rightarrow$ & $\downarrow$ & $\downarrow$ & $\downarrow$ & $\downarrow$ & $\uparrow$ \\
\hline $\begin{array}{l}\text { Anaerobic } \\
\text { Digestion }\end{array}$ & Digestate & $\downarrow$ & $\downarrow$ & $\uparrow$ & $\uparrow$ & $\uparrow$ & $\downarrow$ & $\downarrow$ & $\downarrow^{1}$ & $\uparrow^{2}$ \\
\hline $\begin{array}{l}\text { Drying } \\
\text { Dy }\end{array}$ & Dried manure & $\uparrow$ & $\uparrow$ & $\downarrow$ & $\rightarrow$ & $\downarrow$ & $\downarrow$ & $\downarrow$ & $\downarrow$ & $\uparrow$ \\
\hline Pyrolysis & Biochar & $\uparrow$ & $\rightarrow$ & $\rightarrow / \uparrow^{3}$ & $\downarrow$ & $\uparrow$ & $\downarrow$ & $\downarrow$ & $\downarrow$ & $\uparrow 4$ \\
\hline
\end{tabular}

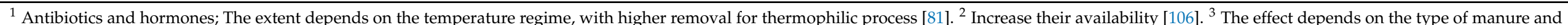

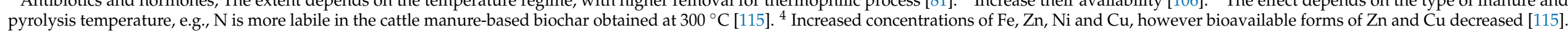




\section{Alternative Uses for Manures or Manure-Based Products}

In Europe, manure-based fertilizers are applied to soil to supply nutrients to conventional crops, in many cases connected with livestock farms (e.g., grassland, cereals) [20], or other arable crops, like maize [116]. There are few studies on alternative uses of manurebased fertilizers, but good examples were found for horticulture (Table 3), or, less frequently, orchards (Table 4), those being the two systems which appeared more often, as recognized by other authors $[20,117]$.

The main objectives of the first studies were centred in the fertilizing potential of the manure-based fertilizers, relatively to mineral fertilizers or to other biowaste-derived fertilizers (e.g., biosolids, municipal solid waste compost), evaluating the effects on soil nutritional status and on fruit/plant quality and yield [118-122], while recent studies are more concerned about environmental issues, mainly those which have an impact in climate change and its mitigation, like $\mathrm{C}$ sequestration [117], gaseous emissions, namely $\mathrm{N}_{2} \mathrm{O}$ and $\mathrm{CH}_{4}$ [123-126], as well as nutrient cycling [126]. Some of these studies have, in fact, pointed to some scenarios where the GHG balance was more negative for organic than for conventional farming [124]. However, it is important to highlight that the use of organic-based fertilizers (namely those based on manures), represent an optimized $\mathrm{N}$ fertilizing strategy in a circular economy perspective, contributing to the nutrients loop and to the decrease in the environmental impacts from the overburden use of mineral fertilizers in horticultural systems [126], and from the excessive production of slurries and manures in areas with a high density of livestock systems. Hence, the problems related to emissions should always be seen from a global perspective, and in some cases, the use of treated slurries or manures can obviate some of the problems associated with GHG emissions from the production of chemical fertilizers. Sustainability needs to be seen globally, and organic waste management is considered a sustainable practice, at least when associated with intensive agriculture systems, like in industrial horticulture [127]. Pardo et al. [117] have tried to evidence this, evaluating if there was a real possibility to contribute to $C$ sequestration in orchards and horticulture systems in Spanish Mediterranean coastal areas, with treated (e.g., composted or digested) or non-treated livestock manure (the current scenario), as well as with other conservation agricultural practices. They have observed that manure anaerobic digestion or composting, as a single measure, did not result in significant changes of soil organic C, but if GHG emissions and savings from manure storage and processing management stages were considered, significant reductions in $\mathrm{CO}_{2}$ emissions could be obtained from anaerobic digestion $\left(4.3 \mathrm{CO}_{2} \mathrm{eq} \mathrm{yr}^{-1}\right)$ and composting

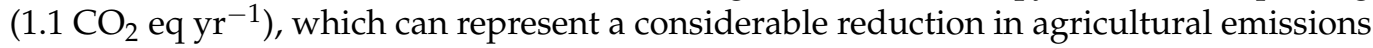
in Spain [117].

The use of manure-based fertilizers in horticultural crops is a very common practice in some Mediterranean countries, like Spain and Italy (Table 3). Sanchez-Martín et al. [123] have highlighted one important potential of this practice, particularly in these semiarid areas with low organic $C$ content, which is the combination of organic fertilizer (applied before or at the time of sowing), with drip-irrigation (DI) systems, only with water, because it is cheaper than fertirigation. The authors have evaluated the combination of anaerobically digested pig slurry, applied before melon plantation, with DI, aiming to reduce $\mathrm{N}_{2} \mathrm{O}$ emissions, compared with the more traditional furrow irrigation (FI) [123]. They have managed to prove that the application of organic fertilizers enhances denitrification (and $\mathrm{N}_{2} \mathrm{O}$ emissions), however, the water distribution pattern in DI favoured nitrification conditions relatively to $\mathrm{FI}$, decreasing $\mathrm{N}_{2} \mathrm{O}$ emissions by $28 \%$ from one system to the other, enabling water savings and the re-use of organic amendments [123]. Moreover, at the end of the experiment there were no significant differences in $\mathrm{N}_{2} \mathrm{O}$ emissions between the two irrigation systems, which is also very important. The pre-treatment of pig slurry, in this case with anaerobic digestion, was pointed by the authors as very important from the environmental point of view, because it reduces the pathogen load, changes the slurry composition, eliminating a significant proportion of volatile organic compounds, which 
minimizes the emissions of odours, homogenizes and reduces the viscosity of the final product, favouring its application and distribution in the soil [123]. This means that the combination of treated slurries, associated with DI, represents a very good option in the context of industrial horticulture in Mediterranean countries [123].

In fact, the major limitation to the use of manure-based fertilizers in horticulture is related to the potential presence of pathogens, which could contaminate the fresh products thereof, endangering human health [128-131]. Actually, even though there are other possible sources of fresh products contamination with microbial pathogens (e.g., irrigation water, wild animal faeces, insects) [132], the manure-based fertilizers are of paramount importance $[130,131,133,134]$ as seen in previous sections. Pathogens identified as of greatest concern were Salmonella (found in tomatoes, seed sprouts and spices) and Escherichia coli O157:H7 (on leafy greens, like spinach and lettuce) [128], and the major problems identified were associated with the use of untreated manure, like in some African countries, e.g., Rwanda, where 50\% of the farms used untreated manures [135]. On the contrary, Denis et al. [136] examined bacterial contamination in fresh fruits and vegetables sold at retail in Canada and found that the prevalence of bacterial contamination was very low, $0-0.08 \%$ in tomatoes and $0.79-1.3 \%$ in leafy herbs, emphasizing the low bacteriological hazards for vegetables available in Canada. Moreover, higher bacterial contamination rates were confirmed in the summer, and in organic as opposed to conventional products [136]. In fact, due to the more common use of animal manure as fertilizer in organic agriculture, the microbial safety of its products, relatively to conventionally grown products with mineral fertilization only, is sometimes critical, and several studies on this subject found that the fresh products from organic farms, namely vegetables, were more susceptible to faecal contamination $[131,136,137]$.

Therefore, animal slurry hygienization is crucial for its safe use in horticulture, to avoid crop contamination, and the application of treatments for manure hygienization should be considered, broadening the range of possibilities of manure use $[60,130,138]$. As discussed before, the reduction and control of microorganisms can be carried out by microbiological, chemical, or physical methods [63], because the storage, despite being the most popular and cheapest method to handle certain types of animal manures [64], may be insufficient to ensure their complete hygienization. Julien-Javaux et al. [131] alerted to the fact that the mitigation of the microbiological risk must start at the farm level, and Guidance Manuals are available, like the one from the Food Standards Agency (UK), with practical advice on how to reduce the risk of contamination of ready-to-eat crops when using manures to improve soil fertility [139].

Organic farming is one interesting market for manures and slurries, or their derived products, like the anaerobic digestate of cattle slurry or organic fertilizers based on dried cattle manure or composted manures $[140,141]$. These authors have been evaluating the application of this type of fertilizers in horticultural organic farming (e.g., lettuce, tomato) in a combination with other agro-ecological techniques (e.g., soil surface shaping, crop rotations, cover crops introduction, and cover crop termination techniques), to adapt to the predicted climatic changes in the Mediterranean area. In fact, the changes in temperature, total seasonal precipitation, potential increase in frequency of droughts and floods, could affect crop growth and lead to a decrease in yield, and the application of organic fertilizers can be a possibility to increase soil fertility to cope with these problems [140-142]. The fact that the organic fertilizers produced with animal manures can be used in organic farming can be a very promising perspective in the coming years, because the European Commission (EC) delivered the "Farm to Fork Strategy", which is at the heart of the European Green Deal aiming to make food systems fair, healthy and environmentally friendly. Organic farming is an environmentally friendly practice that the EC wants to see further developed. The objectives are ambitious: the EC will boost the development of the EU organic farming area with the aim to achieve $25 \%$ of the total farmland under organic farming by 2030. This policy will implicate an increase in the consumption of organic fertilizers, which can be seen as an advantage to the valorisation of animal manures. 
However, the restrictions for the use of the different animal manures in organic farming should be considered: products from intensive livestock facilities, without associated land, are not allowed in organic farming (see previous Section 2).

Orchards are another important option for animal manure valorisation. In this case, the main constraints to the application of manure-based fertilizers are linked to the feasibility of the process. Gioelli et al. [20] have identified this problem in the Piedmont region (Northwest Italy), where the area occupied by orchards is very extensive (more than 63,000 ha) and, quite often, very close to livestock farms interested in exporting their excess $\mathrm{N}$. However, despite the viability of the transport with high volume slurry tanks, and the application with commonly used spreaders, capable of delivering low application rates of $\mathrm{N}$ per ha $\left(<50 \mathrm{~kg} \mathrm{~N} \mathrm{ha}^{-1}\right)$, there are some inconveniences: (i) when higher application rates are needed, that would imply several passages of the tractor, contributing to soil compaction problems; (ii) the slurry would need to be evenly distributed, which is very difficult, giving its heterogeneity; (iii) the number of passages would have to be rigorously calculated, to avoid nutrient losses; and (iv) last but not least, the slurry spreaders would need to fit within the orchard rows, which are usually narrow-wide, with about $4 \mathrm{~m}$, but variable from $3 \mathrm{~m}$ in short rotation forestry, to $5-6 \mathrm{~m}$ in hazel groves $[20,143]$. Due to all these constraints, a prototype band spreader with an automatic rate controller was developed, enabling the application of slurry and its solid fraction to different orchards [20,143]. This device could break the negative attitude of the farmers who are not in favour of its use, mainly due to the lack of adequate machinery, and prefer chemical fertilizers [144], leading to an increased depletion of soil organic matter content. The prototype spreader was designed, constructed, and tested to confer to the users the evenness of the distribution, application rate accuracy and working capacity [20,143]. The authors described thoroughly the prototype developed that has the advantage of having a spreader that accommodates a wide range of settings to fit different row spacing and operating conditions, allowing the spread of animal slurries evenly in narrowly space orchards [143]. Moreover, it has an electronic automatic rate controller, with target application rates ranging from 10 to $120 \mathrm{~kg} \mathrm{~N} \mathrm{ha}^{-1}$, which can be controlled from an onboard computer, with simple and clear settings and display [143]. The authors have tested the prototype in a peach orchard and, besides other advantages, mainly operational (which are important to the farmers), they were able to reduce ammonia emissions by $63 \%$, when compared to the common broadcast application systems by splash plate [20].

Another alternative use of animal manure fertilizers is in the plantation of shortrotation intensive cultures, like fast-growing willow [145], or Eucalyptus globulus [146], which have high nutritional and water requirements, being good "sinks" for the pig slurry produced in different areas. In this case, the risk to human health from the use of untreated slurries and manures is minimum, at least if the application rates are well balanced to prevent water pollution with nutrients and pathogens.

One other possibility is the old integrated crop-livestock farming. Although this could be an "exotic" solution, it should be considered once a reverse trend in intensification is reaching us rapidly. In fact, extensive rearing systems are considered interesting nowadays, due to their positive effects on meat quality, animal welfare and health [147], and, in this case, the environmental impacts associated with the high-land use demands for grazing would be overcome [147]. These authors have combined free-range livestock and tree crops, to improve sustainability in agriculture. They have used a Life Cycle Assessment (LCA) approach to evaluate the environmental impact of combining free-range poultry with olive orchards. In the past, it was common to rear chickens in fruit orchards, which provides a win-win solution: trees benefit chickens in terms of protection from predators, sun, wind, and extreme temperatures, increasing the time and amount of grazing, while the orchard benefits from a reduced need for fertilization and weed control. From an overall perspective, this system results in less land use, reduced erosion, increases in crop yields, soil biological activity and nutrient recycling [147]. The overall impact reduction of the chickens grazing in orchards was, approximately, 30\%, approaching $100 \%$ if land use 
was not considered, once grazing is associated to the orchards area, without the need of extra pasture area. The results are applicable to other combinations of livestock and crops, turning this into a strategy that should be considered nowadays [147].

Table 3. Examples of manure and animal slurry valorisation in horticulture.

\begin{tabular}{|c|c|c|c|c|c|}
\hline Horticulture & Country & Type of Slurry/Manure & Main Aim of the Study & $\begin{array}{l}\text { Main Outcomes Related to } \\
\text { Manure Valorisation }\end{array}$ & Reference \\
\hline $\begin{array}{l}\text { Basil (Ocimum basilicum } \\
\text { "Dark Opal") and tomato } \\
\text { Lycopersicon esculentum } \\
\text { "Charger F1") }\end{array}$ & Not referred & $\begin{array}{c}\text { Composted swine } \\
\text { lagoon sludge with } \\
\text { peanut hulls }(15: 85 \mathrm{v} / \mathrm{v}) \\
\text { to produce a transplant } \\
\text { media (SLC) }\end{array}$ & $\begin{array}{l}\text { Evaluate the use of } \\
\text { composted swine } \\
\text { lagoon sludge as a } \\
\text { nutrient-rich alternative } \\
\text { to peat as } \\
\text { transplant media }\end{array}$ & $\begin{array}{l}\text { The transplant media } \\
\text { produced with composted } \\
\text { swine lagoon sludge } \\
\text { evidenced as a good } \\
\text { substitute for peat, with } \\
\text { tomato and basil transplants } \\
\text { with similar or higher dry } \\
\text { weight than those produced } \\
\text { in either the organic matter } \\
\text { mixture or the control }\end{array}$ & [148] \\
\hline $\begin{array}{c}\text { French basil (Ocimum } \\
\text { basilicum L. cv. Vikas Sudha) }\end{array}$ & Morocco & Farmyard manure & $\begin{array}{l}\text { Effect of organic } \\
\text { manures and inorganic } \\
\text { fertilizer on growth, } \\
\text { herb and oil yield, } \\
\text { nutrient accumulation, } \\
\text { and oil quality of } \\
\text { French Basil }\end{array}$ & $\begin{array}{l}\text { Combined application of } \\
\text { manure and inorganic } \\
\text { fertilizer helps to increase } \\
\text { crops productivity and } \\
\text { quality, and maintaining } \\
\text { soil fertility }\end{array}$ & [149] \\
\hline $\begin{array}{l}\text { Tomato (Solanum } \\
\text { lycopersicum L. cv. Donald) } \\
\text { (organic production) }\end{array}$ & Italy (Southern) & $\begin{array}{c}\text { Anaerobic digestate } \\
\text { fertilizer based on cattle } \\
\text { slurry, and a } \\
\text { commercial organic } \\
\text { fertilizer based on dried } \\
\text { cattle manure }\end{array}$ & $\begin{array}{l}\text { Evaluate the best } \\
\text { synergistic combination } \\
\text { of agro-ecological } \\
\text { techniques to adapt to } \\
\text { the predicted changes in } \\
\text { temperature and total } \\
\text { seasonal precipitation in } \\
\text { the Mediterranean area }\end{array}$ & $\begin{array}{l}\text { In the first year of the study, } \\
\text { the combination of } \\
\text { commercial organic fertilizer } \\
\text { and vetch, as cover crop, } \\
\text { gave both the highest tomato } \\
\text { marketable and total yields }\end{array}$ & [140] \\
\hline $\begin{array}{c}\text { Lettuce (Lactuca sativa var. } \\
\text { longifolia } \\
\text { Lam.) } \\
\text { (organic production) }\end{array}$ & Italy (Southern) & $\begin{array}{c}\text { Anaerobic digestate } \\
\text { fertilizer based on cattle } \\
\text { slurry, and a } \\
\text { commercial organic } \\
\text { fertilizer based on dried } \\
\text { cattle manure }\end{array}$ & $\begin{array}{l}\text { Evaluate the response of } \\
\text { organic lettuce to cover } \\
\text { crop management and } \\
\text { organic fertilisation } \\
\text { (effects on yield, } \mathrm{N} \\
\text { status and } \\
\mathrm{N} \text { utilisation efficiency) }\end{array}$ & $\begin{array}{l}\text { Using a vetch cover crop } \\
\text { before the lettuce, } \\
\text { terminated by the no-till } \\
\text { roller-crimper strategy in } \\
\text { combination with the use of } \\
\text { organic fertilizers assured a } \\
\text { satisfactory response to the } \\
\text { variability in Mediterranean } \\
\text { weather, in terms of both } \\
\text { yield stability and } \\
\text { preservation of soil fertility }\end{array}$ & [141] \\
\hline Spinash (Spinacia olearacea) & Spain (Southeast) & $\begin{array}{l}\text { Several organic-based } \\
\text { stabilized materials } \\
\text { (e.g., vermicompost } \\
\text { from cow manure, } \\
\text { digestate from an } \\
\text { anaerobic digestor fed } \\
\text { with } 30 \% \text { pig slurry and } \\
70 \% \text { sludge from tomato } \\
\text { processing plant), etc. }\end{array}$ & $\begin{array}{l}\text { Evaluate the use of } \\
\text { novel fertilizers that } \\
\text { fulfil the N } \\
\text { requirements of the } \\
\text { crop, but helping to } \\
\text { decrease environmental } \\
\text { impacts and achieve } \\
\text { C-neutral horticulture } \\
\text { (enhance soil C stocks } \\
\text { and reduce GHG } \\
\text { emissions) (mainly } \\
\text { animal manure and } \\
\text { slurry-based fertilizers) }\end{array}$ & $\begin{array}{l}\text { Some of these materials } \\
\text { evidenced multiple positive } \\
\text { effects, on crop quality (i.e., } \\
\mathrm{N} \text { leaf content), and crop } \\
\text { yields, with } 150 \mathrm{~kg} \mathrm{~N} \mathrm{ha}^{-1} \\
\text { application rate: similar } \\
\text { yields to those of } \\
\text { slow-release synthetic } \\
\text { fertilizers lower } \mathrm{NO}_{3}{ }^{-} \\
\text {concentration in spinach } \\
\text { leaves. Direct } \mathrm{N}_{2} \mathrm{O} \text { emissions } \\
\text { were generally low for } \\
\text { manure-based products, } \\
\text { helping to achieve circular } \\
\text { economy, closing the } \\
\text { nutrient loops, and } \\
\text { contributing to } \\
\text { GHG mitigation potential. }\end{array}$ & [126] \\
\hline $\begin{array}{c}\text { Cucumber } \\
\text { (Cucumis sativus L.) }\end{array}$ & $\begin{array}{c}\text { Spain } \\
\text { (Segura river valley, } \\
\text { South East Spain) }\end{array}$ & $\begin{array}{l}\text { Raw and composted } \\
\text { solid fraction of } \\
\text { pig slurry }\end{array}$ & $\begin{array}{l}\text { Effect of different } \\
\text { application rates of raw } \\
\text { and composted solid } \\
\text { fraction of pig slurry, } \\
\text { versus conventional } \\
\text { mineral fertilization, on } \\
\text { major nutrients NPK } \\
\text { contents in different } \\
\text { plant parts of cucumber } \\
\text { (stems, leaves } \\
\text { and fruits) }\end{array}$ & $\begin{array}{l}\text { Similar or higher yields of } \\
\text { fruit and biomass were } \\
\text { obtained using raw or } \\
\text { composted solid fraction of } \\
\text { pig slurry, relatively to the } \\
\text { mineral fertilization } \\
\left(300 \mathrm{~kg} \mathrm{~N} \mathrm{ha}^{-1}\right) \text {, when using } \\
\text { the equivalent to } \\
300 \mathrm{~kg} \mathrm{~N} \mathrm{ha}^{-1} \text { and } \\
450 \mathrm{~kg} \mathrm{~N} \mathrm{ha}^{-1} \text {, but } \\
\text { increasing rates did not } \\
\text { result in increased yields. }\end{array}$ & [121] \\
\hline
\end{tabular}


Table 3. Cont

\begin{tabular}{|c|c|c|c|c|c|}
\hline Horticulture & Country & Type of Slurry/Manure & Main Aim of the Study & $\begin{array}{l}\text { Main Outcomes Related to } \\
\text { Manure Valorisation }\end{array}$ & Reference \\
\hline $\begin{array}{l}\text { Cucumber (Cucumis sativus } \\
\text { L.) and Milan cabbage } \\
\text { (Brassica oleracea L. } \\
\text { var. capitata) }\end{array}$ & $\begin{array}{l}\text { Spain (Segura river } \\
\text { valley, } \\
\text { South East Spain) }\end{array}$ & $\begin{array}{l}\text { Raw and composted } \\
\text { solid fraction of } \\
\text { pig slurry }\end{array}$ & $\begin{array}{l}\text { Study the effect of } \\
\text { application of pig } \\
\text { manure on the } \\
\text { micronutrient (Fe, Cu, } \\
\text { Mn, and } \mathrm{Zn} \text { ) } \\
\text { concentration in } \\
\text { horticultural } \\
\text { plants in calcareous } \\
\text { soils, which induce the } \\
\text { immobilization of } \\
\text { these elements. }\end{array}$ & $\begin{array}{l}\text { Micronutrient concentration } \\
\text { in both plants was affected } \\
\text { by the amendment, with an } \\
\text { increase of Mn and } \mathrm{Zn} \\
\text { uptake and a decrease of Cu, } \\
\text { compared to the control. The } \\
\text { increasing application rate } \\
\left(300 \mathrm{~kg} \mathrm{~N} \mathrm{ha}^{-1} \text { and }\right. \\
\left.450 \mathrm{~kg} \mathrm{~N} \mathrm{ha}^{-1}\right) \text { did not } \\
\text { induce a general increase in } \\
\text { the plant uptake of } \\
\text { micronutrients, except for } \\
\text { the crops grown in soils } \\
\text { amended with the } \\
\text { composted solid fraction of } \\
\text { pig slurry }\end{array}$ & {$[119,120]$} \\
\hline $\begin{array}{l}\text { Melon (Cucumis melo L. } \\
\text { cv. Sancho) }\end{array}$ & Spain & $\begin{array}{l}\text { Anaerobically digested } \\
\text { pig slurry }\end{array}$ & $\begin{array}{c}\text { Evaluate the } \\
\text { combination of } \\
\text { anaerobically digested } \\
\text { pig slurry, applied } \\
\text { before melon plantation, } \\
\text { with drip-irrigation, } \\
\text { aiming to reduce } \mathrm{N}_{2} \mathrm{O} \\
\text { emissions, compared } \\
\text { with the more } \\
\text { traditional } \\
\text { furrow irrigation }\end{array}$ & $\begin{array}{l}\text { Water distribution pattern in } \\
\text { drip-irrigation favoured } \\
\text { nitrification conditions, } \\
\text { relatively to furrow } \\
\text { irrigation, decreasing } \mathrm{N}_{2} \mathrm{O} \\
\text { emissions by } 28 \% \text { from one } \\
\text { system to the other, without } \\
\text { a global increase in } \\
\text { NO emissions }\end{array}$ & [123] \\
\hline Pepper, lettuce and tomato & $\begin{array}{l}\text { Spain } \\
\text { (South East Spain) }\end{array}$ & Pig slurry & $\begin{array}{l}\text { Evaluate the influence } \\
\text { of pig slurry } \\
\text { applications on the } \\
\text { nutrient composition of } \\
\text { three horticultural } \\
\text { crops, grown on two } \\
\text { calcareous soils, under } \\
\text { irrigated conditions }\end{array}$ & $\begin{array}{l}100 \mathrm{~m}^{3} \mathrm{ha}^{-1} \text { pig slurry was } \\
\text { the optimum dose for } \mathrm{N} \\
\text { nutrition of the crops, } \\
\text { independent of the number } \\
\text { of previous applications, } \\
\text { while the doses to satisfy the } \\
\mathrm{P} \text { nutrition decreased with } \\
\text { the number of applications. } \\
\text { For } \mathrm{K}, 100-150 \mathrm{~m}^{3} \mathrm{ha}^{-1} \text { were } \\
\text { required for adequate plant } \\
\text { nutrition, but highly } \\
\text { dependent on the amount of } \\
\text { clay and cation } \\
\text { exchange capacity }\end{array}$ & [150] \\
\hline $\begin{array}{l}\text { Greenhouse lettuce (Lactuca } \\
\text { sativa L. cv. Esperie) }\end{array}$ & Portugal & $\begin{array}{l}\text { Composts from the } \\
\text { solid fraction of dairy } \\
\text { cattle slurry }\end{array}$ & $\begin{array}{l}\text { Evaluate the effects of } \\
\text { increasing rates of } \\
\text { mineral N fertilizer } \\
\text { combined with } \\
\text { composts from the solid } \\
\text { fraction of dairy cattle } \\
\text { slurry on lettuce yield } \\
\text { and N uptake }\end{array}$ & $\begin{array}{l}\text { Lettuce yield and } \mathrm{N} \text { uptake } \\
\text { increased with compost } \\
\text { application ( } 30 \mathrm{t} \mathrm{ha}^{-1} \\
\text { maturated and less } \\
\text { maturated), relatively to the } \\
\text { mineral fertilizer, suggesting } \\
\text { other benefits in addition to } \\
\mathrm{N} \text { availability resulting from } \\
\text { its use as a soil amendment }\end{array}$ & [122] \\
\hline
\end{tabular}

Table 4. Examples of manure and animal slurry valorisation in orchards.

\begin{tabular}{|c|c|c|c|c|c|}
\hline Orchard Type & Country & $\begin{array}{c}\text { Type of Slurry/Manure } \\
\text { and Treatment }\end{array}$ & Main Aim of the Study & $\begin{array}{l}\text { Main Outcomes Related to } \\
\text { Manure Valorization }\end{array}$ & Reference \\
\hline $\begin{array}{l}\text { Mango and } \\
\text { litchi orchards }\end{array}$ & $\begin{array}{l}\text { China (Guangxi and } \\
\text { Hainan provinces) }\end{array}$ & $\begin{array}{c}\text { Manure } \\
\text { (unspecified specie) }\end{array}$ & $\begin{array}{c}\text { To determine the effects of } \\
\text { organic fertilizer (manure) } \\
\text { on arbuscular mycorrhizal } \\
\text { fungal (AMF) } \\
\text { communities in the } \\
\text { rhizospheric soil of litchi } \\
\text { and mango orchards } \\
\text { affected by manure input }\end{array}$ & $\begin{array}{c}\text { SOC resulting from increased } \\
\text { manure input had a direct } \\
\text { positive effect on AMF richness, } \\
\text { but excessive use of manure is } \\
\text { detrimental to AMF occurrence, } \\
\text { mainly associated with increased } \\
\text { available-P. } \\
\text { Manure inputs ranged between } \\
0-0.75 \mathrm{~kg} \text { plant }^{-1} \text { year }^{-1} \text { for litchi }^{-} \\
\text {and } 0-0.60 \mathrm{~kg} \mathrm{plant}^{-1} \text { year }^{-1} \\
\text { for mango. }\end{array}$ & [151] \\
\hline $\begin{array}{c}\text { Peach } \\
\text { (Prunus persica L. } \\
\text { Batsch, Springtime } \\
\text { and } \\
\text { Redhaven cultivars) }\end{array}$ & Greece & Cattle manure & $\begin{array}{l}\text { Response to different } \\
\text { fertilizers combinations, } \\
\text { including mineral NPK } \\
\text { fertilizers and manure }(10 \\
\text { years study, from the } 5 \text { th } \\
\text { to the } 14 \text { th year of the } \\
\text { productive life of trees) }\end{array}$ & 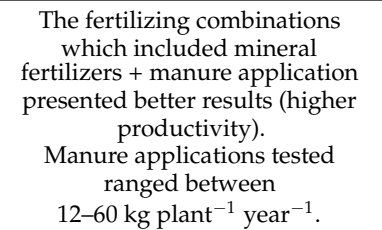 & [118] \\
\hline
\end{tabular}


Table 4. Cont.

\begin{tabular}{|c|c|c|c|c|c|}
\hline Orchard Type & Country & $\begin{array}{c}\text { Type of Slurry/Manure } \\
\text { and Treatment }\end{array}$ & Main Aim of the Study & $\begin{array}{c}\text { Main Outcomes Related to } \\
\text { Manure Valorization }\end{array}$ & Reference \\
\hline $\begin{array}{l}\text { Nectarine } \\
\text { (Prunus persica L. } \\
\text { Batsch, Spring } \\
\text { Bright cultivar) }\end{array}$ & $\begin{array}{l}\text { Italy } \\
\text { (Cuneo province, } \\
\text { Northern) }\end{array}$ & $\begin{array}{l}\text { Swine slurry. } \\
\text { Liquid slurry, covered } \\
\text { slurry, solid fraction }\end{array}$ & $\begin{array}{l}\text { Possibility of application } \\
\text { of swine effluent as } \\
\text { fertilizer vs. mineral } \\
\text { fertilizer evaluating } \\
\text { orchard productivity and } \\
\text { fruit quality }\end{array}$ & $\begin{array}{l}\text { No differences were observed in } \\
\text { orchard productivity and fruit } \\
\text { quality using swine liquid } \\
\text { manure as fertilizer (early results) }\end{array}$ & {$[144,152]$} \\
\hline $\begin{array}{c}\text { Apple orchard } \\
\text { "Golden Delicious" } \\
\text { (Malus domestica Bork) }\end{array}$ & Iran (Zanjan) & $\begin{array}{c}\text { Cow and poultry } \\
\text { manures } \\
\text { (deep litter incorporation) }\end{array}$ & $\begin{array}{l}\text { Evaluate the impact of } \\
\text { animal manure } \\
\text { application on soil } \\
\text { chemistry, mineral } \\
\text { nutrients, yield, fruit } \\
\text { quality and } \\
\text { biological activity }\end{array}$ & $\begin{array}{l}\text { Application of deep litter cow } \\
\text { manure at } 30 \mathrm{t} \mathrm{ha}^{-1} \text { or deep litter } \\
\text { poultry manure at } 10 \mathrm{t} \mathrm{ha}^{-1} \\
\text { resulted in increased yield and } \\
\text { fruit size, but decreased fruit } \\
\text { colour; rate of manure } \\
\text { application correlated with soil } \\
\text { OM; and poultry manure } \\
\text { increased soil } \mathrm{K}, \mathrm{Mg}, \mathrm{Ca}, \\
\text { ammonium-N, and EC levels }\end{array}$ & [153] \\
\hline
\end{tabular}

Fall-applied compost dairy manure (CDM) was more effective at enhancing soil the effects of the the tree water stress compared to composted dairy manure Spring applied. Soil water

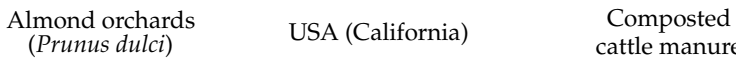
(abundant source of OM for the farmers in the area) and the timing of its application on soil moisture, soil water retention and tree water status of a young orchard

\section{retention $(0-100 \mathrm{kPa}$ at $0-10 \mathrm{~cm})$}

retention $(0-100 \mathrm{kPa}$ at $0-10 \mathrm{~cm})$
increased $13 \%$, compared to the

control, after 2-years application

of $9 \mathrm{t} \mathrm{CDM} \mathrm{ha}{ }^{-1}$, in the fall, as surface mulch.

Young trees may be protected

from periods of limited water

supply using organic matter

amendments, due to their buffer capacity.

\begin{tabular}{|c|c|c|c|c|c|}
\hline Peach orchards & $\begin{array}{l}\text { Italy (Piedmont } \\
\text { region-Northwest) }\end{array}$ & $\begin{array}{l}\text { Solid fraction of } \\
\text { pig slurry }\end{array}$ & $\begin{array}{l}\text { Develop a prototype } \\
\text { spreader for band } \\
\text { application in orchards, } \\
\text { electronically controlled, } \\
\text { with a wide range of } \\
\text { settings, to fit different } \\
\text { row spacings and } \\
\text { operating conditions }\end{array}$ & $\begin{array}{l}\text { The prototype spreader was } \\
\text { designed, constructed, and tested, } \\
\text { allowing the spread of solid } \\
\text { fraction of animal slurries, evenly } \\
\text { in narrowly space orchards, with } \\
\text { considerable reductions in } \\
\text { ammonia emissions }\end{array}$ & {$[20,143]$} \\
\hline Peach orchard & China (Taihu region) & Organic manure & $\begin{array}{l}\text { Evaluate the effects of } \\
\text { chemical fertilizers versus } \\
\text { organic manure in soil } \\
\mathrm{N}_{2} \mathrm{O} \text { and NO emissions }\end{array}$ & $\begin{array}{l}\text { The fertilized peach orchard in } \\
\text { this region (converted from a } \\
\text { rice-wheat rotation), results in an } \\
\text { important source of } \mathrm{N}_{2} \mathrm{O} \\
\text { emissions. However, the } \mathrm{NO} \\
\text { emissions, which were enhanced } \\
\text { eight-fold by the mineral } \\
\text { fertilization, alone or in } \\
\text { combination with organic } \\
\text { manure, were lower with the } \\
\text { organic fertilizer alone }\end{array}$ & [125] \\
\hline $\begin{array}{l}\text { Citrus orchard } \\
\text { (Citrus sinensis) }\end{array}$ & $\begin{array}{c}\text { Sorocaba } \\
\text { Municipality, São } \\
\text { Paulo, Brazil }\end{array}$ & $\begin{array}{l}\text { Organic fertilizer with } \\
78.8 \% \text { poultry litter }\end{array}$ & $\begin{array}{c}\text { Evaluate gaseous } \\
\text { emissions from soils }\left(\mathrm{CO}_{2},\right. \\
\left.\mathrm{CH}_{4}, \mathrm{~N}_{2} \mathrm{O}\right) \text { after the } \\
\text { conversion from a forest to } \\
\text { orange orchard submitted } \\
\text { to organic management } \\
\text { versus } \\
\text { conventional farming }\end{array}$ & $\begin{array}{l}\text { The results were not positive, } \\
\text { apparently: organic management } \\
\text { increased } \mathrm{N}_{2} \mathrm{O} \text { emissions, and the } \\
\text { GHG balance was more negative } \\
\text { for organic than for conventional } \\
\text { farming ( } \mathrm{N} \text { emission factor for } \\
\text { organic fertilizer was } 3.14 \text {, while } \\
\text { for inorganic fertilizer was } 1.47 \text { ). } \\
\text { However, the only factor in the } \\
\text { equation was the gases emissions } \\
\text { from soils }\end{array}$ & [124] \\
\hline Apple orchard & $\begin{array}{c}\text { Shandong Peninsula, } \\
\text { China }\end{array}$ & $\begin{array}{l}\text { Rabbit dung and } \\
\text { chicken manure }\end{array}$ & $\begin{array}{l}\text { Compare apple } \\
\text { production (yields and } \\
\text { economic benefits) under } \\
\text { organic management } \\
\text { relative to the } \\
\text { conventional } \\
\text { management, with } \\
\text { synthetic fertilizers, } \\
\text { herbicides, pesticides, etc. }\end{array}$ & $\begin{array}{l}\text { Apple yield in organic } \\
\text { management treatment } \\
\text { significantly increased by } 30 \% \text {, } \\
\text { relative to the conventional } \\
\text { management, and the quality of } \\
\text { the fruits also increased. Soil } \\
\text { physicochemical properties were } \\
\text { improved, and the practice is } \\
\text { economically advantageous }\end{array}$ & [154] \\
\hline Olives grove & Central Italy & $\begin{array}{l}\text { Poultry manure } \\
\text { (free-range } \\
\text { poultry system) }\end{array}$ & $\begin{array}{c}\text { Perform an LCA to } \\
\text { evaluate the benefits of } \\
\text { combining free-range } \\
\text { livestock (e.g., chicken) } \\
\text { with orchards (e.g., olives), } \\
\text { a common system in } \\
\text { the past }\end{array}$ & $\begin{array}{l}\text { The overall impact reduction was } \\
\text { approximately } 30 \% \text {, approaching } \\
100 \% \text { if land use was not } \\
\text { considered. The results are } \\
\text { applicable to other combinations } \\
\text { of livestock and crops. }\end{array}$ & [147] \\
\hline
\end{tabular}




\section{Farmers and Society Acceptance}

When considering the sustainability of activity, besides the economic viability and the environmental soundness, it is very important not to neglect its third dimension, which is social acceptability [127]. De Silva and Forbes [127] evaluated the sustainability of the horticulture industry in New Zeeland and highlighted the need for growers to be better informed about the process of adoption of sustainable practices and the benefits that can be achieved. Several approaches are possible, including the use of education through industry networks and the sharing of best practices. In industrial horticulture in New Zeeland, already $74.5 \%$ of the producers voluntarily implemented organic waste management practices [127].

Case et al. [155], in Denmark, have made a thorough survey about the farmers' perceptions on the use of organic waste products as fertilizers. In this study, participants were asked to rank the three most important barriers to the use of organic fertilizers, which were: unpleasant odour for neighbours, uncertainty in nutrient content and difficulty in planning and use. On the other hand, the main advantages pointed out were improved soil structure, followed by low cost to buy or produce, and ease of availability.

Case et al. [155] have mentioned that few studies have specifically considered manure and organic fertilizer adoption or acceptance by farmers [156-158]. In a survey of 111 Dutch dairy farmers, Gebrezgabher et al. [157] found that lower age, lower education level, larger farm size and a positive attitude towards the future of the farm, increased interest in the adoption of manure separation technologies. Núñez and McCann [158] found that transportation costs, odour, awareness of others using manure and low off-farm income, were major factors affecting the willingness of arable farmers to accept manure in a study of 138 American crop farmers. On the other hand, Battel [159] emphasized that extension educators have paramount importance to help farmers reducing nonpoint $\mathrm{P}$ loading into surface waters and tried to discover the main factors to encourage farmers to transfer or exchange manure from livestock farms to the fields of neighbouring crop farms. He evaluated farmers' willingness to exchange manure from one farm to another, based on the farmers' age and farm size, in the context of the Michigan State (USA), and found that agronomic considerations were the dominant concerns, separating younger farmers from older ones, and farmers with large properties from those with small properties [159]. Particularly, younger farmers and large landowners were more concerned about (i) using manure containing weed seeds, (ii) the fact that manure application equipment could cause compaction, and (iii) the fact that manure application could interfere with the time schedule of some field activities [159]. On the other hand, older farmers are less willing to accept a neighbouring farmers' manure, more even if they had to pay for it. One opinion was common to all the inquired farmers: irrespective of their age or farm size, they all agreed that their major concern is if the neighbours complain about the odour associated with manure application, being this the most significant barrier to manure use [159].

In Denmark, over half of arable/horticulture farmers used at least one type of organic fertilizer, most frequently unprocessed manures, and there is a high degree of manure export from livestock farms to pure arable farms. However, these numbers are a consequence of the regulatory regime in Denmark, which requires harmony between livestock and available land, forcing farmers with manure in excess to export the surplus to neighbouring arable farms [155]. In the Case et al. study [155], more than $66 \%$ of farmers that used organic fertilizer chose unprocessed manures, mainly slurry or farmyard manure, whereas just fewer than $20 \%$ used processed manures, mainly anaerobically digested or acidified slurry. However, it is important to refer that only $9 \%$ of the overall respondents used urban waste-derived fertilizer, mainly sewage sludge in raw or processed form, and the probable causes that were identified were the limited local access to any manure, either unprocessed or processed, i.e., they would prefer manure-based fertilizers if they had that possibility. Taking this into consideration, one option for increasing the use of animal waste-derived organic fertilizers could be to develop a network between the livestock producers, with surplus production of manure and slurry, and the farmers in areas with no access to manure. 
Case et al. [155], among other initiatives, proposes the creation of regional/district virtual "marketplaces" or trading platforms for surplus raw or processed manures.

In most cases, there are no networks developed for the export of nutrients from one livestock farmer to the producers. Bluemling and Wang [160] identified that gap, and presented a paper introducing a cooperative in Sichuan province (China) which connects livestock farms to crop farms that are willing to use imported manure as fertilizer. A framework was developed, based on the "brokerage" concept, helping to close the nutrients cycling in that province. They identified manure processing and manure management issues as the bottlenecks in this framework [160], but this type of structure could be an important solution to the nutrients cycling in the sector, being able to create an organized market associated with animal manures valorisation.

\section{Conclusions}

Animal manure management must be considered as an opportunity to promote circularity and mitigate $\mathrm{NH}_{3}$ and GHG emissions. As seen, the legal framework for manure utilization in the EU can help the adoption of manure as fertilizer. However, there is the need to overcome what are considered as the main limitations for its use. For that, several strategies can be used, producing a variety of manure-based fertilizers. It has also been shown that horticulture and orchards can be an alternative market for manure-based fertilizers. Nevertheless, it is still necessary to build up society and farmers' acceptance of this proposed solution.

Author Contributions: Conceptualization, D.F., P.A. and R.F.; data collection, D.F., P.A. and R.F.; funding acquisition, D.F.; writing — original draft, D.F., P.A. and R.F.; writing—review and editing, D.F., P.A. and R.F. All authors have read and agreed to the published version of the manuscript.

Funding: This research was funded by (1) the Project Nutri2Cycle: H2020-SFS-30-2017- "Transition towards a more carbon and nutrient efficient agriculture in Europe", funded from the European Union, Program Horizon 2020 (Grant Agreement No 773682); (2) the Project CleanSlurry PTDC/ASPSOL/28769/2017, "Animal slurry hygienization for use in industrial horticulture" funded by Fundação para a Ciência e Tecnologia (FCT), (3) LEAF (Linking Landscape, Environment, Agriculture and Food Research Unit), funded by FCT (UID/AGR/04129/2020). This document re-flects only the authors' view and the Union is not liable for any use that may be made of the in-formation contained therein.

Institutional Review Board Statement: Not applicable.

Informed Consent Statement: Not applicable.

Data Availability Statement: Not applicable.

Conflicts of Interest: The authors declare no conflict of interest. The funders had no role in the design of the study; in the collection, analyses, or interpretation of data; in the writing of the manuscript; or in the decision to publish the results.

\section{References}

1. FAO (Food and Agriculture Organization of the United Nations). Global Agriculture towards 2050. High Level Expert Forum Issues Paper; FAO: Rome, Italy, 2009; p. 4.

2. United Nations, Department of Economic and Social Affairs, Population Division. World Population Prospects 2019: Highlights; United Nations: New York, NY, USA, 2019; p. 40.

3. Rojas-Downing, M.M.; Nejadhashemi, A.P.; Harrigan, T.; Woznicki, S.A. Climate change and livestock: Impacts, adaptation, and mitigation. Clim. Risk Manag. 2017, 16, 145-163. [CrossRef]

4. European Commission. EU Agricultural Outlook for the Agricultural Markets and Income 2017-2030; Publications Office of the European Union: Luxembourg, 2017; p. 100.

5. Eurostat. Agri-Environmental Indicator-Livestock Patterns; Fact sheet of the European Union: Brussels, Belgium, $2019 ;$ p. 12.

6. Animal Task Force (ATF). A Strategic Research and Innovation Agenda for a Sustainable Livestock Sector in Europe; Second White Paper, Short Version; Animal Task Force: Paris, France, 2017; p. 50.

7. Marquer, P.; Rabade, T.; Forti, R. Pig Farming in the European Union: Considerable Variations from One Member State to Another. Statistics in Focus; Eurostat: Kirchberg, Luxembourg, 2014; p. 13. 
8. Augère-Granier, M.L. The EU Poultry Meat and Egg Sector. Main Features Challenges and Prospects; European Union: Brussels, Belgium, 2019; p. 29. [CrossRef]

9. Ihle, R.; Dries, L.; Jongeneel, R.; Venus, T.; Wesseler, J. Research for Agri Committee-The EU Cattle Sector: Challenges and OpportunitiesMilk and Meat; European Union: Brussels, Belgium, 2017; p. 176. [CrossRef]

10. Clay, N.; Garnett, T.; Lorimer, J. Dairy intensification: Drivers, impacts and alternatives. Ambio 2020, 49, 35-48. [CrossRef] [PubMed]

11. Foged, H.L.; Flotats, X.; Bonmati Blasi, A.; Palatsi, J.; Magri, A.; Martin Schelde, K. Technical Report No. I Concerning "Manure Processing Activities in Europe" to the European Commission. In Inventory of Manure Processing Activities in Europe; Directorate-General Environment: Brussels, Belgium, 2011; p. 138.

12. Sheldrick, W.; Syers, J.K.; Lingard, J. Contribution of livestock excreta to nutrient balances. Nutr. Cycl. Agroecosyst. 2003, 66, 119-131. [CrossRef]

13. Potter, P.; Ramankutty, N.; Bennett, E.M.; Donner, S.D. Characterizing the spatial patterns of global fertilizer application and manure production. Earth Interact. 2010, 14, 1-22. [CrossRef]

14. Leip, A.; Achermann, B.; Billen, G.; Sutton, M.A.; Howard, C.M.; Brownlie, W.J.; Skiba, U.; Hicks, K.; Winiwarter, W.; van Grinsven, H.; et al. Integrating nitrogen fluxes at the European scale. In The European Nitrogen Assessment; Sutton, M.A., Howard, C.M., Erisman, J.W., Billen, G., Bleeker, A., Eds.; Cambridge University Press: Cambridge, UK, 2011; pp. 345-376.

15. Oenema, O.; Oudendag, D.; Velthof, G.L. Nutrient losses from manure management in the European Union. Livest. Sci. 2007, 112, 261-272. [CrossRef]

16. Leip, A.; Billen, G.; Garnier, J.; Grizzetti, B.; Lassaletta, L.; Reis, S.; Simpson, D.; Sutton, M.A.; de Vries, W.; Weiss, F.; et al. Impacts of European livestock production: Nitrogen, sulphur, phosphorus and greenhouse gas emissions, land-use, water eutrophication and biodiversity. Environ. Res. Lett. 2015, 10, 115004. [CrossRef]

17. Fernández, M.T.; Herrero Mallén, E.; Bescós Roy, B. LIFE + MANEV: Evaluation of Manure Management Systems and Treatment Technologies in Europe; SARGA: Zaragoza, Spain, 2015; p. 180.

18. Hjorth, M.; Christensen, K.V.; Christensen, M.L.; Sommer, S.G. Solid-liquid separation of animal slurry in theory and practice. A review. Agron. Sustain. 2010, 30, 153-180. [CrossRef]

19. Fangueiro, D.; Hjorth, M.; Gioelli, F. Acidification of animal slurry-a review. J. Environ. Manag. 2015, 149, 46-56. [CrossRef]

20. Gioelli, F.; Balsari, P.; Dinuccio, E.; Airoldi, G. Band application of slurry in orchards using a prototype spreader with an automatic rate controller. Biosyst. Eng. 2014, 121, 130-138. [CrossRef]

21. Hijbeek, R.; Pronk, A.A.; van Ittersum, M.K.; Verhagen, J.; Ruysschaert, G.; Bijttebier, J.; Zavattaro, L.; Bechini, L.; Schlatter, N.; ten Berge, H.F.M. Use of organic inputs by arable farmers in six agro-ecological zones across Europe: Drivers and barriers. Agric. Ecosyst. Environ. 2019, 275, 42-53. [CrossRef]

22. Sommer, S.G.; Oenema, O.; Matsunaka, T.; Jensen, L.S. Regulations on Animal Manure Management. In Animal Manure Recycling; Sommer, S.G., Christensen, M.L., Schmidt, T., Jensen, L.S., Eds.; John Wiley \& Sons Ltd.: Chichester, UK, 2013; pp. 25-39. [CrossRef]

23. EU regulation No 1069/2009 of the European Parliament and of the Council. Available online: https:/ / eur-lex.europa.eu/legalcontent/en/ALL/?uri=CELEX\%3A32009R1069 (accessed on 23 November 2020).

24. EU Regulation No 1306/2013 of the European Parliament and of the council. Available online: https:/ / eur-lex.europa.eu/legalcontent/en/ALL/?uri=CELEX\%3A32013R1306 (accessed on 23 November 2020).

25. Lal, R. Soil carbon sequestration impacts on global climate change and food security. Science 2004, 304, 1623-1627. [CrossRef] [PubMed]

26. Lal, R. Beyond COP 21: Potential and challenges of the "4 per Thousand" initiative. J. Soil Water Conserv. 2016, 71, 20A-25A. [CrossRef]

27. Frelih-Larsen, A.; Bowyer, C.; Albrecht, S.; Keenleyside, C.; Kemper, M.; Nanni, S.; Naumann, S.; Mottershead, D.; Landgrebe, R.; Andersen, E.; et al. Updated Inventory and Assessment of Soil Protection Policy Instruments in EU Member States; Ecologic Institute: Berlin, Germany, 2016; p. 462.

28. EU Directive 2010/75/EU of the European Parliament and of the Council. Available online: https:/ / eur-lex.europa.eu/legalcontent/EN/TXT/?uri=celex:32010L0075 (accessed on 1 July 2020).

29. EU Directive 006/118/EC of the European Parliament and of the Council. Available online: https:/ / eurlex.europa.eu/eli/dir/20 06/118/oj (accessed on 1 July 2020).

30. EU Directive 2000/60/EC of the European Parliament and of the Council. Available online: https:/ / eur-lex.europa.eu/legalcontent/EN/TXT/?uri=celex:32000L0060 (accessed on 1 July 2020).

31. De Boer, H.C. Nitrate Leaching from Liquid Cattle Manure Compared to Synthetic Fertilizer Applied to Grassland or Silage Maize in The Netherlands; Report 1055; Wageningen Livestock Research: Wageningen, The Netherlands, 2017; p. 28.

32. Jiao, W.; Chen, W.; Chang, A.C.; Page, A.L. Environmental risks of trace elements associated with long-term phosphate fertilizers applications: A review. Environ. Pollut. 2012, 168, 44-53. [CrossRef] [PubMed]

33. Roberts, T.L. Cadmium and phosphorous fertilizers: The issues and the science. Proc. Eng. 2014, 83, 52-59. [CrossRef]

34. EU Directive 91/676/EEC of the European Parliament and of the Council. Available online: https:/ / eur-lex.europa.eu/legalcontent/EN/ALL/?uri=CELEX:32014D0112 (accessed on 1 July 2020). 
35. Huygens, D.; Orveillon, G.; Lugato, E.; Tavazzi, S.; Comero, S.; Jones, A.; Gawlik, B.; Saveyn, H.G.M. Technical Proposals for the Safe Use of Processed Manure above the Threshold Established for Nitrate Vulnerable Zones by the Nitrates Directive (91/676/EEC); Publications Office of the European Union: Luxembourg, 2020; p. 170. JRC121636. [CrossRef]

36. Directorate-General for Climate of the European Commission: Climate strategies \& targets. Available online: https: / ec.europa. eu/clima/policies/strategies_en (accessed on 30 June 2020).

37. Chai, R.; Ye, X.; Ma, C.; Wang, Q.; Tu, R.; Zhang, L.; Gao, H. Greenhouse gas emissions from synthetic nitrogen manufacture and fertilization for main upland crops in China. Carbon Balance Manag. 2019, 14, 20. [CrossRef] [PubMed]

38. Chadwick, D.; Sommer, S.G.; Thorman, R.; Fangueiro, D.; Cardenas, L.; Amon, B.; Misselbrook, T. Manure management: Implications for greenhouse gas emissions. Anim. Feed Sci. Tech. 2011, 166-167, 514-531. [CrossRef]

39. EU Directive 2016/2284 of the European Parliament and of the Council. Available online: https:/ / eur-lex.europa.eu/legalcontent/EN/TXT/?uri=uriserv\%3AOJ.L_.2016.344.01.0001.01.ENG (accessed on 1 July 2020).

40. Directorate-General for Environment of the European Commission: Circular Economy. Available online: https: / / ec.europa.eu/ environment/circular-economy/index_en.htm (accessed on 10 July 2020).

41. EU Directive 2018/851 of the European Parliament and of the Council. Available online: https:/ / eur-lex.europa.eu/eli/dir/2018 /851/oj (accessed on 1 July 2020).

42. EU Directive 2018/850 of the European Parliament and of the Council. Available online: https:/ / eurlex.europa.eu/eli/dir/2018 /850/ oj (accessed on 1 July 2020).

43. EU Regulation 2019/1009 of the European Parliament and of the Council. Available online: https://eur-lex.europa.eu/eli/reg/ 2019/1009/oj (accessed on 1 July 2020).

44. Nazzaro, C.; Marotta, G. The Common Agricultural Policy 2014-2020: Scenarios for the European agricultural and rural systems. Agric. Econ. 2016, 4, 16. [CrossRef]

45. Directorate-General Agriculture and Rural Development: The Post-2020 Common Agricultural Policy: Environmental Benefits and Simplification. Available online: https://ec.europa.eu/info/news/environmental-care-and-climate-change-objectivesfuture-cap-2019-jan-25_en (accessed on 1 July 2020).

46. EU Regulation 2018/848 of the European Parliament and of the Council. Available online: https:/ / eur-lex.europa.eu/legalcontent/EN/TXT/?uri=uriserv\%3AOJ.L_.2018.150.01.0001.01.ENG (accessed on 1 July 2020).

47. Brown, C. Available Nutrients and Value for Manure from Various Livestock Types; Ontario Ministry of Agriculture and Food and the Ministry of Rural Affairs@; Queen's Printer for Ontario: Toronto, ON, Canada, 2013; p. 8.

48. Van Bruggen, C. Review of Mineral Contents in Livestock Manure-Actualisation of Anex I of Implementing Regulation for the Fertilizer Act; Statisitics Netherlands (CBS): Wageningen, The Netherlands, 2014. (In Dutch)

49. Fangueiro, D.; Surgy, S.; Fraga, I.; Monteiro, F.G.; Cabral, F.; Coutinho, J. Acidification of animal slurry affects the nitrogen dynamics after soil application. Geoderma 2016, 281, 30-38. [CrossRef]

50. Maltais-Landry, G.; Scow, K.; Brennan, E.; Torbert, E.; Vitousek, P. Higher Flexibility in input N:P ratios results in more balanced phosphorus budgets in two long-term experimental agroecosystems. Agric. Ecosyst. Environ. 2016, 223, 197-210. [CrossRef]

51. Eurostat (2017) Agriculture-Ammonia Emission Statistics. Available online: http://ec.europa.eu/eurostat/statisticsexplained/ (accessed on 3 July 2020).

52. Feilberg, A.; Liu, D.; Adamsen, A.; Hansen, M.; Jonassen, K. Odorant emissions from intensive pig production measured by online proton-transfer-reaction mass spectrometry. Environ. Sci. Technol. 2010, 44, 5894-5900. [CrossRef]

53. Parker, D.B.; Gilley, J.; Woodbury, B.; Kim, K.H.; Galvin, G.; Bartelt-Hunt, S.L.; Li, X.; Snow, D.D. Odorous VOC emission following land application of swine manure slurry. Atmos. Environ. 2013, 66, 91-100. [CrossRef]

54. Yaacoby, T.; Goldwasser, T.; Paporish, A.; Rubin, B. Germination of Phelipanche aegyptiaca and Cuscuta campestris seeds in composted farm manure. Crop. Protect. 2015, 72, 76-82. [CrossRef]

55. Colbach, N.; Tschudy, C.; Meunier, D.; Houot, S.; Nicolardot, B. Weed seeds in exogenous organic matter and their contribution to weed dynamics in cropping systems. A simulation approach. Eur. J. Agronom. 2013, 45, 7-19. [CrossRef]

56. De Cauwer, B.; D’Hose, T.; Cougnon, M.; Leroy, B.; Bulcke, R.; Reheul, D. Impact of the quality of organic amendments on size and composition of the weed seed bank. Weed Res. 2010, 51, 250-260. [CrossRef]

57. Miyazawa, K.; Tsuji, H.; Yamagata, M.; Nakano, H.; Nakamoto, T. Response of weed flora to combinations of reduced tillage, biocide application and fertilization practices in a 3-year crop rotation. Weed Biol. Manag. 2004, 4, 24-34. [CrossRef]

58. Eghball, B.; Lesoing, G.W. Viability of weed seeds following manure windrow composting. Compost Sci. Util. 2000, 8, 46-53. [CrossRef]

59. Westerman, P.; Gerowitt, B. Weed seed survival during anaerobic digestion in biogas plants. Bot. Rev. 2013, 79, 281-316. [CrossRef]

60. Alegbeleye, O.O.; Sant'Ana, A.S. Manure-borne pathogens as an important source of water contamination: An update on the dynamics of pathogen survival/transport as well as practical risk mitigation strategies. Int. J. Hyg. Environ. Health 2020, 227, 113524. [CrossRef]

61. Liang, Z.; He, Z.; Powell, C.A.; Stoffella, P.J. Survival of Escherichia coli in soil with modified microbial community composition. Soil Biol. Biochem. 2011, 43, 1591-1599. [CrossRef]

62. Semenov, A.V.; Van Overbeek, L.; Termorshuizen, A.J.; Van Bruggen, A.H.C. Influence of aerobic and anaerobic conditions on survival of Escherichia coli O157: H7 and Salmonella enterica serovar Typhimurium in Luria-Bertani broth, farm-yard manure and slurry. J. Environ. Manag. 2011, 92, 780-787. [CrossRef] 
63. Heinonen-Tanski, H.; Mohaibes, M.; Karinen, P.; Koivunen, J. Methods to reduce pathogen microorganisms in manure. Livest. Sci. 2006, 102, 248-255. [CrossRef]

64. Skowron, K.; Olszewska, H.; Skowron, K.; Paluszak, P.; Breza-Boruta, B. Hygienic aspect of cattle slurry storage as most popular and cheapest method of handling liquid animal excrements. Ann. Anim. Sci. 2013, 13, 597-609. [CrossRef]

65. García-Orenes, F.; Morugán-Coronado, A.; Zornoza, R.; Scow, K. Changes in soil microbial community structure influenced by agricultural management practices in a Mediterranean agro-ecosystem. PLoS ONE 2013, 8, e80522. [CrossRef] [PubMed]

66. Drummond, J.D.; Davies-Colley, R.J.; Stott, R.; Sukias, J.P.; Nagels, J.W.; Sharp, A.; Packman, A.I. Microbial transport, retention, and inactivation in streams: A combined experimental and stochastic modeling approach. Environ. Sci. Technol. 2015, 49, 7825-7833. [CrossRef] [PubMed]

67. Krog, J.S.; Forslund, A.; Larsen, L.E.; Dalsgaard, A.; Kjaer, J.; Olsen, P.; Schultz, A.C. Leaching of viruses and other microorganisms naturally occurring in pig slurry to tile drains on a well-structured loamy field in Denmark. Hydrogeol. J. 2017, 25, 1045-1062. [CrossRef]

68. Sepehrnia, N.; Memarianfard, L.; Moosavi, A.A.; Bachmann, J.; Guggenberger, G.; Rezanezhad, F. Bacterial mobilization and transport through manure enriched soils: Experiment and modeling. J. Environ. Manag. 2017, 201, 388-396. [CrossRef] [PubMed]

69. Fangueiro, D.; Surgy, S.; Napier, V.; Menaia, J.; Vasconcelos, E.; Coutinho, J. Impact of slurry management strategies on potential leaching of nutrients and pathogens in a sandy soil amended with cattle slurry. J. Environ. Manag. 2014, 146, 198-205. [CrossRef]

70. Sarmah, A.K.; Meyer, M.T.; Boxall, A.B.A. A global perspective on the use, sales, exposure pathways, occurrence, fate and effects of veterinary antibiotics (VAs) in the environment. Chemosphere 2016, 65, 725-759. [CrossRef]

71. Pan, X.; Qiang, Z.; Ben, W.; Chen, M. Residual veterinary antibiotics in swine manure from concentrated animal feeding operations in Shandong Province, China. Chemosphere 2011, 84, 695-700. [CrossRef]

72. Tavazzi, S.; Mariani, G.; Skejø, H.; Comero, S.; Głowacka, N.; Gaduš, J.; Gawlik, B.M. Residues of Antimicrobial Agents and Related Compounds of Emerging Concern in Manure, Water and Soil. Part 1, Pilot-Sampling Campaign in Slovakia and First Findings; Publications Office of the European Union: Luxembourg, 2018; p. 58. [CrossRef]

73. Ghirardini, A.; Grillini, V.; Verlicchi, P. A Review of the occurrence of selected micropollutants and microorganisms in different raw and treated manure-environmental risk due to antibiotics after application to soil. Sci. Total Environ. 2020, 707, 136118. [CrossRef]

74. Hou, J.; Wan, W.; Mao, D.; Wang, C.; Mu, Q.; Qin, S.; Luo, Y. Occurrence and distribution of sulfonamides, tetracyclines, quinolones, macrolides, and nitrofurans in livestock manure and amended soils of northern China. Environ. Sci. Pollut. Res. 2015, 22, 4545-4554. [CrossRef] [PubMed]

75. Alvarenga, P.; Carneiro, J.P.; Fangueiro, D.; Cordovil, C.M.S.D.; Bernal, M.P. Chapter 5-Managing organic amendments in agroecosystems to enhance soil carbon storage and mitigate climate change. In Climate Change and Soil Interactions; Prasad, M.N.V., Pietrzykowski, M., Eds.; Elsevier: Amsterdam, The Netherlands, 2020; pp. 89-141. [CrossRef]

76. Liu, Z.; Wang, X. Chapter 26-Manure treatment and utilization in production systems. In Animal Agriculture; Bazer, F.W., Lamb, G.C., Wu, G., Eds.; Academic Press: Cambridge, MA, USA, 2020; pp. 455-467. [CrossRef]

77. Burton, C.H.; Turner, C. Manure Management: Treatment Strategies for Sustainable Agriculture; Silsoe Research Institute: Bedford, UK, 2003; pp. 178-179.

78. Lin, H.; Sun, W.; Yu, Q.; Ma, J. Acidic conditions enhance the removal of sulfonamide antibiotics and antibiotic resistance determinants in swine manure. Environ. Pollut. 2020, 263, 114439. [CrossRef]

79. Duerschner, J.; Bartelt-Hunt, S.; Eskridge, K.M.; Gilley, J.E.; Li, X.; Schmidt, A.M.; Snow, D.D. Swine slurry characteristics as affected by selected additives and disinfectants. Environ. Pollut. 2020, 260, 114058. [CrossRef]

80. Burton, C.H. The potential contribution of separation technologies to the management of livestock manure. Livest. Sci. 2007, 112, 208-216. [CrossRef]

81. Oliver, J.P.; Gooch, C.A.; Lansing, S.; Schueler, J.; Hurst, J.J.; Sassoubre, L.; Crossette, E.M.; Aga, D.S. Invited review: Fate of antibiotic residues, antibiotic-resistant bacteria, and antibiotic resistance genes in US dairy manure management systems. J. Dairy Sci. 2020, 103, 1051-1071. [CrossRef] [PubMed]

82. Martinez, J.; Dabert, P.; Barrington, S.; Burton, C. Livestock waste treatment systems for environmental quality, food safety, and sustainability. Bioresour. Technol. 2009, 100, 5527-5536. [CrossRef]

83. Larney, F.J.; Hao, X. A review of composting as a management alternative for beef cattle feedlot manure in southern Alberta, Canada. Bioresour Technol. 2007, 98, 3221-3227. [CrossRef]

84. Bernal, M.P.; Alburquerque, J.A.; Moral, R. Composting of animal manures and chemical criteria for compost maturity assessment. A review, Bioresour. Technol. 2009, 100, 5444-5453. [CrossRef]

85. Millner, P.; Ingram, D.; Mulbry, W.; Arikan, O.A. Pathogen reduction in minimally managed composting of bovine manure. Waste Manag. 2014, 34, 1992-1999. [CrossRef]

86. Erickson, M.C.; Liao, J.; Ma, L.; Jiang, X.; Doyle, M.P. Inactivation of Salmonella spp. in cow manure composts formulated to different initial C: N ratios. Bioresour. Technol. 2009, 100, 5898-5903. [CrossRef]

87. Martens, W.; Böhm, R. Overview of the ability of different treatment methods for liquid and solid manure to inactivate pathogens. Bioresour Technol. 2009, 100, 5374-5378. [CrossRef] [PubMed]

88. Chen, Z.; Jiang, X. Microbiological safety of chicken litter or chicken litter-based organic fertilizers: A review. Agriculture 2014, 4, 1-29. [CrossRef] 
89. Thomas, C.; Idler, C.; Ammon, C.; Amon, T. Effects of the C/N ratio and moisture content on the survival of ESBL-producing Escherichia coli during chicken manure composting. Waste Manag. 2020, 105, 110-118. [CrossRef] [PubMed]

90. Chen, C.; Pankow, C.A.; Oh, M.; Heath, L.S.; Zhang, L.; Du, P.; Xia, K.; Pruden, A. Effect of antibiotic use and composting on antibiotic resistance gene abundance and resistome risks of soils receiving manure-derived amendments. Environ. Int. 2019, 128, 233-243. [CrossRef]

91. Zhang, L.; Gu, J.; Wang, X.; Sun, W.; Yin, Y.; Sun, Y.; Guo, A.; Tuo, X. Behavior of antibiotic resistance genes during co-composting of swine manure with Chinese medicinal herbal residues. Bioresour Technol. 2017, 244, 252-260. [CrossRef]

92. Zhang, L.; Li, L.; Sha, G.; Liu, C.; Wang, Z.; Wang, L. Aerobic composting as an effective cow manure management strategy for reducing the dissemination of antibiotic resistance genes: An integrated meta-omics study. J. Hazard. Mater 2020, $386,121895$. [CrossRef]

93. Havens, S.M.; Hedman, C.J.; Hemming, J.D.C.; Mieritz, M.G.; Shafer, M.M.; Schauer, J.J. Occurrence of estrogens, androgens and progestogens and estrogenic activity in surface water runoff from beef and dairy manure amended crop fields. Sci. Total Environ. 2020, 710, 136247. [CrossRef]

94. Hazarika, J.; Ghosh, U.; Kalamdhad, A.S.; Khwairakpam, M.; Singh, J. Transformation of elemental toxic metals into immobile fractions in paper mill sludge through rotary drum composting. Ecol. Eng. 2017, 101, 185-192. [CrossRef]

95. Chen, Y.X.; Huang, X.D.; Han, Z.Y.; Huang, X.; Hu, B.; Shi, D.Z.; Wu, W.X. Effects of bamboo charcoal and bamboo vinegar on nitrogen conservation and heavy metals immobility during pig manure composting. Chemosphere 2010, 78, 1177-1181. [CrossRef]

96. Kumar, S.; Negi, S.; Mandpe, A.; Singh, R.V.; Hussain, A. Rapid composting techniques in Indian context and utilization of black soldier fly for enhanced decomposition of biodegradable wastes-a comprehensive review. J. Environ. Manag. 2018, 227, 189-199. [CrossRef]

97. Lalander, C.; Diener, S.; Zurbrugg, C.; Vinneras, B. Effects of feedstock on larval development and process efficiency in waste treatment with black soldier fly (Hermetia illucens). J. Clean. Prod. 2019, 208, 211-219. [CrossRef]

98. Liu, T.; Awasthi, M.K.; Chen, H.C.; Duan, Y.; Awasthi, S.K.; Zhang, Z. Performance of black soldier fly larvae (Diptera: Stratiomyidae) for manure composting and production of cleaner compost. J. Environ. Manag. 2019, 251, 109593. [CrossRef] [PubMed]

99. Calvet, S.; Hunt, J.; Misselbrook, T.H. Low frequency aeration of pig slurry affects slurry characteristics and emissions of greenhouse gases and ammonia. Biosyst. Eng. 2017, 159, 121-132. [CrossRef] [PubMed]

100. Nag, R.; Auer, A.; Markey, B.K.; Whyte, P.; Nolan, S.; O’Flaherty, V.; Russell, L.; Bolton, D.; Fenton, O.; Richards, K.; et al. Anaerobic digestion of agricultural manure and biomass-Critical indicators of risk and knowledge gaps. Sci. Total Environ. 2019, 690, 460-479. [CrossRef] [PubMed]

101. Ramos-Suárez, J.L.; Ritter, A.; Mata González, J.; Camacho Pérez, A. Biogas from animal manure: A sustainable energy opportunity in the Canary Islands. Renew. Sust. Energ. Rev. 2019, 104, 137-150. [CrossRef]

102. Ma, G.; Ndegwa, P.; Harrison, J.H.; Chen, Y. Methane yields during anaerobic co-digestion of animal manure with other feedstocks: A meta-analysis. Sci. Total Environ. 2020, 728, 138224. [CrossRef] [PubMed]

103. Rabii, A.; Aldin, S.; Dahman, Y.; Elbeshbishy, E. A review on anaerobic co-digestion with a focus on the microbial populations and the effect of multi-stage digester configuration. Energies 2019, 12, 1106. [CrossRef]

104. Fagbohungbe, M.O.; Onyeri, C.A.; Semple, K.T. Co-fermentation of whey permeates and cattle slurry using a partitioned up-flow anaerobic digestion tank. Energy 2019, 185, 567-572. [CrossRef]

105. Yang, S.; Wen, Q.; Chen, Z. Impacts of $\mathrm{Cu}$ and $\mathrm{Zn}$ on the performance, microbial community dynamics and resistance genes variations during mesophilic and thermophilic anaerobic digestion of swine manure. Bioresour. Technol. 2020, 312, 123554. [CrossRef]

106. Thanh, P.M.; Ketheesan, B.; Yan, Z.; Stuckey, D. Trace metal speciation and bioavailability in anaerobic digestion: A review. Biotechnol. Adv. 2016, 34, 122-136. [CrossRef]

107. Gurmessa, B.; Pedretti, E.F.; Cocco, S.; Cardelli, V.; Corti, G. Manure anaerobic digestion effects and the role of pre-and posttreatments on veterinary antibiotics and antibiotic resistance genes removal efficiency. Sci. Total Environ. 2020, 721, 137532. [CrossRef] [PubMed]

108. Georgiou, D.; Liliopoulos, V.; Aivasidis, A. Investigation of an integrated treatment technique for anaerobically digested animal manure: Lime reaction and settling, ammonia stripping and neutralization by biogas scrubbing. Bioresour. Technol. 2019, 5, 127-133. [CrossRef]

109. Kinidi, L.; Tan, I.A.; Abdul Wahab, W.N.B.; Tamrin, K.F.B.; Hipolito, C.N.; Salleh, S.F. Recent development in ammonia stripping process for industrial wastewater treatment. Int. J. Chem. Eng. 2018, 2018, 14. [CrossRef]

110. Menkveld, H.W.H.; Smith, G.O.J. GENIAAL-from manure to green minerals and clean water. Comm. Appl. Biol. Sci. Adv. Trends Biogas Biorefin. 2017, 82, 172-174.

111. Alitalo, A.; Kyro, A.; Aura, E. Ammonia stripping of biologically treated liquid manure. J. Environ. Qual. 2012, 41, 273-280. [CrossRef]

112. Cattaneo, M.; Finzi, A.; Guido, V.; Riva, E.; Provolo, G. Effect of ammonia stripping and use of additives on separation of solids, phosphorus, copper and zinc from liquid fractions of animal slurries. Sci. Total Environ. 2019, 672, 30-39. [CrossRef]

113. Provolo, G.; Perazzolo, F.; Mattachini, G.; Finzi, A.; Naldi, E.; Riva, E. Nitrogen removal from digested slurries using a simplified ammonia stripping technique. Waste Manag. 2017, 69, 154-161. [CrossRef] 
114. Bonmatí, A.; Flotats, X. Air stripping of ammonia from pig slurry: Characterisation and feasibility as a pre-or post-treatment to mesophilic anaerobic digestion. Waste Manag. 2003, 23, 261-272. [CrossRef]

115. Cely, P.; Gascó, G.; Paz-Ferreiro, J.; Méndez, A. Agronomic properties of biochars from different manure wastes. J. Anal. Appl. Pyrolys. 2015, 111, 173-182. [CrossRef]

116. Pedersen, I.F.; Rubæk, G.H.; Nyord, T.; Sørensen, P. Row-injected cattle slurry can replace mineral P starter fertiliser and reduce P surpluses without compromising final yields of silage maize. Eur. J. Agron. 2020, 116, 126057. [CrossRef]

117. Pardo, G.; del Prado, A.; Martínez-Mena, M.; Bustamante, M.A.; Martín, J.A.R.; Álvaro-Fuentes, J.; Moral, R. Orchard and horticulture systems in Spanish Mediterranean coastal areas: Is there a real possibility to contribute to C sequestration? Agric. Ecosyst. Environ. 2017, 238, 153-167. [CrossRef]

118. Chatzitheodorou, I.T.; Sotiropoulos, T.E.; Mouhtaridou, G.I.; Almaliotis, D. Effect of nitrogen, phosphorus, potassium fertilizers and manure on growth and productivity of the peach cultivars Springtime and Redhaven. Hort. Sci. 2004, 31, 88-92. [CrossRef]

119. Moral, R.; Moreno-Caselles, J.; Perez-Murcia, M.D.; Perez-Espinosa, A.; Paredes, C.; Agulló, E. Micronutrient Concentration in Horticultural Crops Grown on a Soil Amended with the Solid Phase of Pig Slurry. Commun. Soil Sci. Plant. Anal. 2006, 37, 2595-2603. [CrossRef]

120. Moral, R.; Moreno-Caselles, J.; Perez-Murcia, M.D.; Perez-Espinosa, A.; Paredes, C.; Bustamante, M.A. Fertilizing Capacity of Fresh and Composted Solid Fraction of Swine Manure on Brassica Oleracea Var. Capitata. In Proceedings of the 14th International Symposium on Fertilizers (CIEC), Debrecen, Hungary, 22-25 June 2003; pp. 683-689.

121. Moral, R.; Moreno-Caselles, J.; Perez-Murcia, M.D.; Perez-Espinosa, A.; Paredes, C.; Sosa, F. The influence of fresh and composted solid fractions of swine manure slurry on yield of cucumber (Cucumis sativus L.). Commun. Soil Sci. Plant Anal. 2005, 36, 517-524. [CrossRef]

122. Brito, L.M.; Amaro, A.L.; Mourão, I.; Coutinho, J. Influence of dairy cattle slurry solid fraction compost combined with mineral nitrogen fertilizer on the growth of greenhouse lettuce. Commun. Soil Sci. Plant Anal. 2012, 43, 2484-2491. [CrossRef]

123. Sanchez-Martín, L.; Meijide, A.; Garcia-Torres, L.; Vallejo, A. Combination of drip irrigation and organic fertilizer for mitigating emissions of nitrogen oxides in semiarid climate. Agric. Ecosyst. Environ. 2010, 137, 99-107. [CrossRef]

124. Escanhoela, A.S.B.; Pitombo, L.M.; Brandani, C.B.; Navarrete, A.A.; Bento, C.B.; do Carmo, J.B. Organic management increases soil nitrogen but not carbon content in a tropical citrus orchard with pronounced $\mathrm{N}_{2} \mathrm{O}$ emissions. J. Environ. Manag. 2019, 234, 326-335. [CrossRef]

125. Cheng, Y.; Xie, W.; Huang, R.; Yan, X.; Wang, S. Extremely high $\mathrm{N}_{2} \mathrm{O}$ but unexpectedly low NO emissions from a highly organic and chemical fertilized peach orchard system in China. Agric. Ecosyst. Environ. 2017, 246, 202-209. [CrossRef]

126. Vico, A.; Sáez, J.A.; Pérez-Murcia, M.D.; Martinez-Tomé, J.; Andreu-Rodríguez, J.; Agulló, E.; Bustamante, M.A.; Sanz-Cobena, A.; Moral, R. Production of spinach in intensive Mediterranean horticultural systems can be sustained by organic-based fertilizers without yield penalties and with low environmental impacts. Agric. Syst. 2020, 178, 102765. [CrossRef]

127. De Silva, T.A.; Forbes, S.L. Sustainability in the New Zealand horticulture industry. J. Clean. Prod. 2016, 112, 2381-2391. [CrossRef]

128. Olaimat, A.N.; Holley, R.A. Factors influencing the microbial safety of fresh produce: A review. Food Microbiol. 2012, 32, 1-19. [CrossRef] [PubMed]

129. Goss, M.J.; Tubeileh, A.; Goorahoo, D. A review of the use of organic amendments and the risk to human health. Adv. Agron. 2013, 120, 275-379. [CrossRef]

130. Alegbeleye, O.O.; Singleton, I.; Sant'Ana, A.S. Sources and contamination routes of microbial pathogens to fresh produce during field cultivation: A review. Food Microbiol. 2018, 73, 177-208. [CrossRef] [PubMed]

131. Julien-Javaux, F.; Gérard, C.; Campagnoli, M.; Zuber, S. Strategies for the safety management of fresh produce from farm to fork. Curr. Opin. Food Sci. 2019, 27, 145-152. [CrossRef]

132. Palese, A.M.; Pasquale, V.; Celano, G.; Figliuolo, G.; Masi, S.; Xiloyannis, C. Irrigation of olive groves in Southern Italy with treated municipal wastewater: Effects on microbiological quality of soil and fruits. Agric. Ecosyst. Environ. 2009, 129, 43-51. [CrossRef]

133. Taban, B.M.; Halkman, A.K. Do leafy green vegetables and their ready-to-eat [RTE] salads carry a risk of foodborne pathogens? Anaerobe 2011, 17, 286-287. [CrossRef]

134. Hoagland, L.; Ximenes, E.; Ku, S.; Ladisch, M. Foodborne pathogens in horticultural production systems: Ecology and mitigation. Sci. Hortic. 2018, 236, 192-206. [CrossRef]

135. Ssemanda, J.N.; Reij, M.W.; van Middendorp, G.; Bouw, E.; van der Plaats, R.; Franz, E.; Muvunyi, C.M.; Bagabe, M.C.; Zwietering, M.H.; Joosten, H. Foodborne pathogens and their risk exposure factors associated with farm vegetables in Rwanda. Food Control 2018, 89, 86-96. [CrossRef]

136. Denis, N.; Zhang, H.; Leroux, A.; Trudel, R.; Bietlot, H. Prevalence and trends of bacterial contamination in fresh fruits and vegetables sold at retail in Canada. Food Control 2016, 67, 225-234. [CrossRef]

137. Oliveira, M.; Usall, J.; Viñas, I.; Anguera, M.; Gatius, F.; Abadias, M. Microbiological quality of fresh lettuce from organic and conventional production. Food Microbiol. 2010, 27, 679-684. [CrossRef]

138. Venglovsky, J.; Martinez, J.; Placha, I. Hygienic and ecological risks connected with utilization of animal manures and biosolids in agriculture. Livest. Sci. 2006, 102, 197-203. [CrossRef] [PubMed]

139. Managing Farm Manures for Food Safety-Guidance for Growers of Ready-to-Eat Crops. Available online: https://www.food.gov. uk/business-guidance/managing-farm-manures-for-food-safety (accessed on 15 September 2020). 
140. Diacono, M.; Persiani, A.; Canali, S.; Montemurro, F. Agronomic performance and sustainability indicators in organic tomato combining different agro-ecological practices. Nutr. Cycl. Agroecosyst. 2018, 112, 101-117. [CrossRef]

141. Testani, E.; Montemurro, F.; Ciaccia, C.; Diacono, M. Agroecological practices for organic lettuce: Effects on yield, nitrogen status and nitrogen utilisation efficiency. Biol. Agric. Hortic. 2020, 36, 84-95. [CrossRef]

142. Lepsch, H.C.; Brown, P.H.; Peterson, C.A.; Gaudin, A.C.M.; Khalsa, S.D.S. Impact of organic matter amendments on soil and tree water status in a California orchard. Agric. Water Manag. 2019, 222, 204-212. [CrossRef]

143. Balsari, P.; Dinuccio, E.; Gioelli, F.; Airoldi, G. Band spreader for the application of slurry solid fractions to orchards. Biosyst. Eng. 2015, 136, 69-76. [CrossRef]

144. Cerutti, A.K.; Beccaro, G.L.; Bounous, G. Nectarine productivity and fruit quality under swine manure fertilization: Methodologies and early results. Acta Hortic. 2012, 962, 333-340. [CrossRef]

145. Cavanagh, A.; Gasser, M.O.; Labrecque, M. Pig slurry as fertilizer on willow plantation. Biomass Bioenerg. 2011, 35 , 4165-4173. [CrossRef]

146. Hooda, A.K.; Weston, C.J.; Chen, D. Denitrification in effluent-irrigated clay soil under Eucalyptus globulus plantation in south-eastern Australia. For. Ecol. Manag. 2003, 179, 547-558. [CrossRef]

147. Paolotti, L.; Boggia, A.; Castellini, C.; Rocchi, L.; Rosati, A. Combining livestock and tree crops to improve sustainability in agriculture: A case study using the Life Cycle Assessment (LCA) approach. J. Clean. Prod. 2016, 131, 351-363. [CrossRef]

148. Noah, A.C.; Herring, P.L.; Kraus, H.T. Suitability of swine lagoon compost as transplant media for basil and tomato. Acta Hortic. 2019, 1266, 375-380. [CrossRef]

149. Anwar, M.; Patra, D.D.; Chand, S.; Alpesh, K.; Naqvi, A.A.; Khanuja, S.P.S. Effect of organic manures and inorganic fertilizer on growth, herb and oil yield, nutrient accumulation, and oil quality of French Basil. Commun. Soil Sci. Plant Anal. 2005, 36, 1737-1746. [CrossRef]

150. Bernal, M.P.; Roig, A. The influence of pig slurry fertilisation on the mineral content of horticultural crops grown in calcareous soils. J. Sci. Food Agric. 1993, 62, 129-135. [CrossRef]

151. Jiang, S.; Hu, X.; Kang, Y.; Xie, C.; An, X.; Dong, C.; Xu, Y.; Shen, Q. Arbuscular mycorrhizal fungal communities in the rhizospheric soil of litchi and mango orchards as affected by geographic distance, soil properties and manure input. Appl. Soil Ecol. 2020, 152, 103593. [CrossRef]

152. Beccaro, G.L.; Cerutti, A.K.; Bounous, G. Nectarine productivity and fruit quality under swine manure fertilization: Results from a three-year field trial. Acta Hortic. 2015, 1084, 305-312. [CrossRef]

153. Amiri, M.E.; Fallahi, E. Impact of animal manure on soil chemistry, mineral nutrients, yield, and fruit quality in "Golden Delicious" Apple. J. Plant Nutr. 2009, 32, 610-617. [CrossRef]

154. Cen, Y.; Li, L.; Guo, L.; Li, C.; Jiang, G. Organic management enhances both ecological and economic profitability of apple orchard: A case study in Shandong Peninsula. Sci. Hortic. 2020, 265, 109201. [CrossRef]

155. Case, S.D.C.; Oelofse, M.; Hou, Y.; Oenema, O.; Jensen, L.S. Farmer perceptions and use of organic waste products as fertilizers-A survey study of potential benefits and barriers. Agric. Syst. 2017, 151, 84-95. [CrossRef]

156. Asai, M.; Langer, V.; Frederiksen, P. Responding to environmental regulations through collaborative arrangements: Social aspects of manure partnerships in Denmark. Livest. Sci. 2014, 167, 370-380. [CrossRef]

157. Gebrezgabher, S.A.; Meuwissen, M.P.M.; Kruseman, G.; Lakner, D.; Oude, L.; Ansink, A.G.J.M. Factors influencing adoption of manure separation technology in The Netherlands. J. Environ. Manag. 2015, 150, 1-8. [CrossRef]

158. Núñez, J.; McCann, L. Crop Farmers' Willingness to Use Manure. In Proceedings of the American Agricultural Economics Association 2004 Annual Meeting, Denver, CO, USA, 1-4 August 2004; p. 25.

159. Battel, R.D. Farmer willingness to enter into manure exchange agreements: Differences based on age and farm size. J. Extension 2006, 44, 3. Available online: https://www.joe.org/joe/2006june/rb4.php (accessed on 2 July 2020).

160. Bluemling, B.; Wang, F. An institutional approach to manure recycling: Conduit brokerage in Sichuan Province, China. Resour. Conserv. Recycl. 2018, 139, 396-406. [CrossRef] 